\title{
Niedynastyczne małżeństwa Jagiellonów i królów elekcyjnych
}

\section{Wprowadzenie}

D awno i stara przypowieść w tej mierze jest takiemu każdemu, który się jedno chce ożenić, aby sobie równą pojął, a nierównej aby nigdy żony nie nabywał [...] tedy przystoi to ojcowi aby gdyby syna z żoną oddać chciał, równej onemu szukał"1. Taką myśl zawarł Erazm Gliczner, w książce poświęconej wychowaniu dzieci, wydanej w Krakowie w 1558 r. ${ }^{2}$ Podobnie wyraził się Stanisław Orzechowski: „Ja, dziewce swej godnego męża a sobie zięcia szukając, patrzę na ród jego, na zacność jego [...]"3. W powyższych wypowiedziach podkreślano znaczenie równości stanowej osób, jako istotnego warunku przy zawieraniu związków małżeńskich. Preferowano łączenie osób z tych samych stanów społecznych, uważając inne postępowanie za nienormalne i gorszące. Zasada ta obowiązywała także w rodzinach królewskich ${ }^{4}$.

Od zasady tej zdarzały się jednak odstępstwa zarówno na dworach Europy Zachodniej, jak i wśród królów polskich. Do zawierania niedynastycznych związków dochodziło na przykład w dynastii Tudorów za

${ }^{1}$ E. Gliczner, Książki o wychowaniu dzieci, przedmowa dr Wł. Wisłocki, Kraków 1876, s. 132. Analogiczną myśl wyraził M. Rej „Nierównego stanu żona niedobra [...] Równemu z równym ożenienie najlepsze". M. Rej z Nagłowic, Żywot człowieka poczciwego, wyd. K. J. Turowski, Kraków 1859, s. 65-66.

${ }^{2}$ E. Gliczner, Książi o wychowaniu..., s. III.

${ }^{3}$ Stanisława Orzechowskiego polskie dialogi polityczne (Rozmowa około egzekucyjej i Quincunx), 1563-1564, wyd. J. Łoś, z objaśnieniami historycznymi S. Kot, Kraków 1919, s. 103.

${ }^{4}$ Przykładem byli Habsburgowie, zob. E. Hubert, A. T. Midro, W mroku genów europejskich rodów panujacych, „Ananke” [biuletyn Galerii im Śleńdzinskich], [Białystok] 2006, nr 1 (45), s. 9-15; S. Grodziski, Habsburgowie, Dzieje dynastii, Kraków 2013, s. 100-107, 109-110. 
panowania Henryka VIII ${ }^{5}$. Podobnie rzecz miała się w monarchii francuskiej, gdy w 1533 r. syn króla Franciszka I Walezjusza, Henryk, książę Orleanu, poślubił Katarzynę de Medici spadkobierczynię rodziny bankierskiej ${ }^{6}$. Taki charakter miał też związek Kazimierza Wielkiego z Krystyna, zwaną przez Długosza Rokiczanka, wdową po rajcy praskim ${ }^{7}$. Za Jagiellonów i królów elekcyjnych na dwadzieścia zawartych związków małżeńskich pięć miało charakter niedynastyczny.

Problematyka związków polskich władców z osobami nie wywodzącymi się z domów panujących w ówczesnej Europie poruszana jest na marginesie prac poświęconych monarchom polskim. O paktach matrymonialnych Jagiellonów traktuje artykuł Urszuli Borkowskiej, jednakże pominięto $\mathrm{w}$ nim kwestię niedynastycznych związków ${ }^{8}$. Małżeństwu Zygmunta Augusta z Barbarą Radziwiłłówną istotne uwagi poświęciła Anna Sucheni-Grabowska w biografii ostatniego z Jagiellonów ${ }^{9}$.

Celem niniejszego artykułu jest przedstawienie okoliczności towarzyszących zawieraniu niedynastycznych związków królów polskich, reakcji otoczenia królewskiego na decyzję panującego oraz jej wpływu na postanowienie powzięte przez władcę.

Przedmiotem naszych rozważań jest pięć małżeństw królów polskich: Władysława II Jagiełły z Elżbietą Granowską, a następnie z Sonką Holszańska, Zygmunta I z Barbarą Zapolya, Zygmunta Augusta z Barbarą Radziwiłłówną i związek Władysława IV Wazy z Ludwiką Marią de Gonzaga (de Nevers).

W artykule omawiamy małżeństwo Władysława IV Wazy z Ludwiką Marią de Gonzaga z tego powodu, że stało się ono dynastycznym wyłącznie w wyniku starań podjętych przez dyplomację polską na żądanie króla Władysława. W negocjacjach poprzedzających zawarcie związku małżeńskiego Władysława IV z Ludwiką Marią uzgodniono, „że wywodzi się ona z Królewskiej gałęzi Burbonów, Alencon, Bourgogne" i uznano ją

${ }^{5}$ Pomijamy nieoficjalne związki monarchów i pochodzące $\mathrm{z}$ nich dzieci nieślubne, zob. T. Szulc, Kochanki i niepraze dzieci królów polskich w okresie elekcyjnym (w świetle ówczesnych relacji), „Studia z Dziejów Państwa i Prawa Polskiego” [Kraków] 2007, t. X, s. 127-145.

${ }^{6}$ J. Héritier, Katarzyna Medycejska, Warszawa 1981, s. 32; B. Cravieri, Kochanki i królowe. Władza kobiet, Warszawa 2008, s. 17.

${ }^{7}$ J. Wyrozumski, Kazimierz Wielki, Wrocław-Warszawa-Kraków-Gdańsk-Łódź 1982, s. 211.

${ }^{8}$ U. Borkowska OSU, „Pacta Matrymonialia” Domu Jagiellonów, „Roczniki Humanistyczne" 2000, Zeszyt Specjalny Historia, t. XLVIII, z. 2 Cursus mille annorum ofiarowane Profesorowi Eugeniuszowi Wiśniowskiemu, s. 44-60.

${ }^{9}$ A. Sucheni-Grabowska, Zygmunt August Król Polski i Wielki Ksiażę Litewski 15201563, Warszawa 1996, s. 126-127, 129-130, 151-159. 
za francuską księżniczkę $\mathrm{krwi}^{10}$. Starania strony polskiej zostały podjęte na skutek krytyki, że monarcha bierze za żonę poddaną obcego władcy. Postanowiono, że Ludwika Maria stanie się równą stanowo królowi polskiemu.

W naszych dociekaniach pominęliśmy małżeństwo Jana Sobieskiego z Marią Kazimierą d'Arquien. Do zawiązania tego związku doszło bowiem w czasie, gdy Jan Sobieski nie był monarcha, z kolei Maria Kazimiera wywodziła się ze zubożałej szlachty francuskiej ${ }^{11}$. $Z$ tego powodu nie uwzględniamy tej pary królewskiej.

Dostępne źródła zawierają materiał, który nierównomiernie rozkłada się na powyżej wymienione niedynastyczne związki matrymonialne. Większą bazą źródłową i literaturą dysponujemy dla związku Zygmunta I i Barbary Zapolyi, Zygmunta II Augusta i Barbary Gasztołdowej Radziwiłłównej i Władysława IV Wazy i Ludwiki Marii de Nevers. Podstawą źródłową tego artykułu są przekazy drukowane ${ }^{12}$.

${ }^{10}$ Księżniczka Ludwika Maria „,non seulement en consideration de Sa Naissance, E de ses grandes $\mathcal{E}$ rares qualitez; mais à cause de la proche parenté, qui la joint à leurs Majestez, estant issue des branches Royales de Bourbon, d`Alençon, E de Bourgogne, E aiant esté ainsi elevée, aupres de la Reine, qui i aime comme sié etoit sa propre Fille [...]" zob. M. Dogiel, Codex diplomaticus Regni et Magni Ducatus Lithuaniae, t. I, cz. 1-2, Vilno 1758, Dok. IX, s. 469. Podobnie w punkcie III kontraktu zamieszczono sformułowanie, że Ludwika Maria dla króla francuskiego "estant sa proche parente, et née des Princesses du Sang Roial” jest bliską krewna, urodzoną z książąt krwi królewskiej, tamże, s. 470; zob. T. Szulc, Status prawnomajątkowy Ludwiki Marii de Gonzaga w świetle intercyz matżeńskich z roku 1645 i 1649, "Studia Prawno-Ekonomiczne" 2015, t. XCVI, s. 150-152.

${ }^{11}$ Z. Wójcik, Jan Sobieski 1629-1696, Warszawa 1983, s. 60-61; T. Szulc, Status materialny Marii Kazimiery Sobieskiej po jej koronacji, „Studia Prawno Ekonomiczne” 2014, t. XCI/1, s. 179-201.

${ }^{12}$ Kroniki, pisma polityczne, prace, pamiętniki, listy: Acta Tomiciana, Marcina Bielskiego, Stanisława Ciołka, Codex diplomaticus Regni Poloniae et Magni Ducatus Lithuaniae, t. I Macieja Dogiela; Jodoka L. Decjusza, Roczniki Jana Długosza, Erazma Glicznera, Françoise B. de Motteville, Stanisława Orzechowskiego, Stanislawa Oświęcima, Pamiętniki do panowania Zygmunta III, Władysława IV i Jana Kazimierza z rękopisu wyd. K. Wł. Wójcicki; Portofolio królowej Maryi Ludwiki, Stanisława Al. Radziwiłła, Mikołaja Reja z Nagłowic, Kardynała Retza, Macieja Stryjkowskiego; Bernarda Wapowskiego; Wesele Zygmunta I z Barbara Zapolska, [w:] M. Wiszniewski, Pomniki historyi i literatury Polskiey, t. IV; Wypis z podróży Pani de Guebriant, posłowej nadzwyczajnej do Polski, za Władystawa IV, [w:] J. U. Niemcewicz, Zbiór pamiętników historycznych o dawnej Polsce..., t. IV, Lipsk 1839; Źródła, [w:] K. Waliszewski, Polsko-francuskie stosunki w XVII wieku. 1644-1667. Opowiadania i źródła historyczne ze zbiorów archiwalnych francuskich publicznych i prywatnych, Kraków 1889. 


\section{Pochodzenie społeczne małżonek królewskich}

Trzecia żona Jagiełly, Elżbieta z Pilczy 3-o voto Granowska ${ }^{13}$, wdowa po zmarłym w 1410 r. staroście generalnym Wielkopolski, Wincentym z Granowa, była córką wojewody sandomierskiego Ottona z Pilczy ${ }^{14}$. Matką jej była Jadwiga Melsztyńska, córka Jana z Melsztyna, kasztelana krakowskiego. Elżbieta pochodziła z rodziny zamożnej, zostawszy po raz kolejny wdową posiadała ogromny majątek. Do zawarcia związku doszło w 1417 r., w rok po śmierci drugiej żony Władysława Jagiełły Anny Cylijskiej ${ }^{15}$.

Do czwartego małżeństwa Władysława Jagieły doszło w roku 1422, w dwa lata po śmierci Elżbiety Granowskiej. Żoną króla została Zofia (Sonka), córka Andrzeja, syna Iwana Olgimuntowicza z Holszan, namiestnika kijowskiego z ramienia Witolda ${ }^{16}$. Ojciec jej, Andrzej, był bratem Julianny Olszańskiej, żony księcia Witolda ${ }^{17}$. Matką Zofii była księżna Aleksandra Dymitrówna Drucka ${ }^{18}$. W momencie zamążpójścia Zofia wraz z siostrami i matką przebywała u brata matki Semena Dymitrowicza Druckiego, który po śmierci jej ojca ${ }^{19}$ był ich opiekunem ${ }^{20}$. Sonka pochodziła z książęcego rodu, tym niemniej, jak pisze Jan Tęgowski, należała do poddanych króla polskiego i wielkiego księcia litewskiego ${ }^{21}$.

${ }^{13}$ Był to dla niej czwarty związek małżeński, Encyklopedyja powszechna, t. VIII, Warszawa 1861, s. 248 s.v. Elżbieta, Helżbieta, z Pilczy (J. Bartoszewicz); A. Prochaska, Długosz o Elżbiecie trzeciej żonie Jagietty, Lwów 1876, s. 15-16.

${ }^{14}$ A. Prochaska, Dtugosz o Elżbiecie..., s. 7, 11, 38-40; Z. Wdowiszewski, Genealogia Jagiellonów i Domu Wazów w Polsce, Kraków 2005, s. 69-71.

${ }^{15}$ Polski słownik biograficzny [dalej: PSB], t. I, Kraków 1935, s. 121 s.v. Anna Cylejska (autor K. Pieradzka); Z. Wdowiszewski, Genealogia Jagiellonów..., s. 67-68.

${ }^{16}$ J. Tęgowski, Przodkowie Zofii Holszańskiej czwartej żony Władysława Jagiełty, [w:] Genealogia. Studia i Materiały Historyczne, t. VIII, red. M. Górny, Poznań-Wrocław 1996, s. 28 29; Z. Wdowiszewski, Genealogia Jagiellonów..., s. 75-76.

${ }^{17}$ Encyklopedia powszechna, t. XXVIII, Warszawa 1868, s. 679 s.v. Zofija, królowa Sońka (autor J. Bartoszewicz); U. Borkowska OSU, Dynastia Jagiellonów w Polsce, Warszawa 2011, s. 489.

${ }^{18}$ Księżna Aleksandra była wnuczką księcia Dymitra Starszego Olgierdowicza, przyrodniego brata Jagiełły, St. M. Kuczyński, Król Jagiełło ok. 1350-1434, Warszawa 1985, s. 85; J. Krzyżaniakowa, J. Ochmański, Władysław II Jagiełło, Wrocław-Warszawa-KrakówGdańsk-Łódź 1990, s. 271. Zdaniem J. Tęgowskiego informacja ta nie znajduje potwierdzenia w źródłach, J. Tęgowski, Przodkowie Zofii..., s. 30.

${ }_{19}$ J. Tęgowski, Pierwsze pokolenie Giedyminowiczów, Poznań-Wrocław 1999, s. 128; Z. Wdowiszewski, Genealogia Jagiellonów..., s. 76.

${ }^{20}$ E. Maleczyńska, Rola polityczna królowej Zofii Holszańskiej na tle walki stronnictw w Polsce w latach 1422-1434, Lwów 1936, s. 24-25 [Archiwum Tow. Nauk. we Lwowie, Dział II, t. XIX, z. 3]; St. M. Kuczyński, Król Jagiełto..., s. 86.

${ }^{21}$ J. Tęgowski, Przodkowie Zofii..., s. 28-32; B. Czwojdrak, Zofia Holszańska. Studium o dworze i roli królowej w późnośredniowiecznej Polsce, Warszawa 2012, s. 16-17. 
Barbara Zapolya, żona Zygmunta I, wywodziła się ze szlacheckiego rodu podległego monarsze węgierskiemu. Ród Zapolyów pod względem zamożności sytuował się na drugim miejscu po rodzinie Korwinów i z racji zajmowanych stanowisk w państwie nadzorował „połowę terenu korony węgierskiej, to znaczy Siedmiogród i Górne Węgry" 22. Ojcem Barbary był jeden z najpotężniejszych magnatów węgierskich Stefan Zapolya, wojewoda siedmiogrodzki ${ }^{23}$, hrabia spiski ${ }^{24}$, a jej matką Jadwiga, córka Przemysła II, księcia cieszyńskiego i Anny, księżniczki mazowieckiej.

Barbara Radziwiłłówna, żona Zygmunta II Augusta, była wdową po wojewodzie nowogródzkim Stanisławie Gasztołdzie, zmarłym w 1542 r., po pięciu latach małżeństwa ${ }^{25}$. Ojcem Barbary był Jerzy Radziwiłł, kasztelan wileński, hetman wielki litewski w latach 1531-154126, a jej dziadkiem Mikołaj, jeden z największych dostojników Wielkiego Księstwa Litewskiego ${ }^{27}$. Matką Barbary była córka wojewody podolskiego Pawła z Dalejowa, również Barbara ${ }^{28}$.

Ludwika Maria de Gonzaga, poddana Ludwika XIV, została żoną Władysława IV Wazy. Była ona księżniczką de Nevers, córką Karola Gonzagi, księcia de Nevers i Katarzyny de Guise, księżnej Maine. Młodszej gałęzi rodu Gonzagów początek dał Ludwik, trzeci syn Fryderyka II, księcia Mantui, osiedliwszy się w połowie wieku XVI we Francji ${ }^{29}$.

${ }^{22}$ M. Rekettyés, Stosunki polityczne i kulturalne polsko-wegierskie za Władysława Jagiellończyka, Wrocław 1999, s. 101-102.

${ }^{23}$ Najwyższa godność na Węgrzech, urzędnika tego wybierał monarcha spośród czterech kandydatów przedstawionych przez Stany. Był on namiestnikiem władcy podczas jego nieobecności i pośrednikiem między nim a stanami, Encyklopedyja powszechna, t. XX, Warszawa 1865, s. 269 s.v. Palatyn (autor Lewestam Fr. H.).

${ }^{24}$ Encyklopedyja powszechna, t. XXVIII, s. 679 s.v. Zofija, królowa Sońka (autor J. Bartoszewicz); PSB, t. I, s. 293, s.v. Barbara Zapola (autor Wł. Pociecha); M. Rekettyés, Stosunki polityczne..., s. 102.

${ }^{25}$ W. Ziembicki, Barbara Radziwiłłówna w oświetleniu lekarskim, [w:] Pamiętnik Szóstego Powszechnego Zjazdu Historyków Polskich w Wilnie 17-20 września 1935 r., t. I, Referaty, do druku przygotował F. Podhorecki, Lwów 1935, s. 144; Z. Wdowiszewski, Genealogia Jagiellonów..., s. 104.

${ }^{26}$ A. Przeździecki, Jagiellonki polskie w XVI wieku. Obraz rodziny i dworu Zygmunta I i Zygmunta Augusta Królów Polskich, t. I, Kraków 1868, s. 183; Z. Kuchowicz, Barbara Radziwiłtówna, Łódź 1976, s. 14.

${ }^{27}$ E. Rudzki, Polskie Królowe. Żony Piastów i Jagiellonów, t. I, Warszawa 1985, s. 245.

${ }^{28}$ A. Dembińska, Zygmunt I. Zarys dziejów wewnętrzno-politycznych w latach 1540-1548, Poznań 1948, s. 287, przyp. 36; PSB, t. I, s. 294 s.v. Barbara Radziwiłtówna (autor: Wł. Pociecha).

${ }^{29}$ Ludwik IV Gonzaga, trzeci syn Fryderyka II, księcia Mantui i markiza Montferatu, wysłany za młodu w interesach rodu na dwór francuski, służył delfinowi, przyszłemu Franciszkowi II. Naturalizował się we Francji. W 1565 r. wstępuje w związek małżeński z Henriettą de Cleve, księżną Nevers i hrabiną Rethel, ostatnią z rodu Cleve. Nabywa tym samym tytuł księcia de Nevers, stając się kuzynem przyszłego króla Henryka IV. Z małżeństwa urodziło się pięcioro dzieci. Ludwik IV dał początek młodszej, francuskiej, linii rodu Gonzaga. W. St. Magdziarz, Anna Austriaczka, Warszawa 2013, s. 77. 


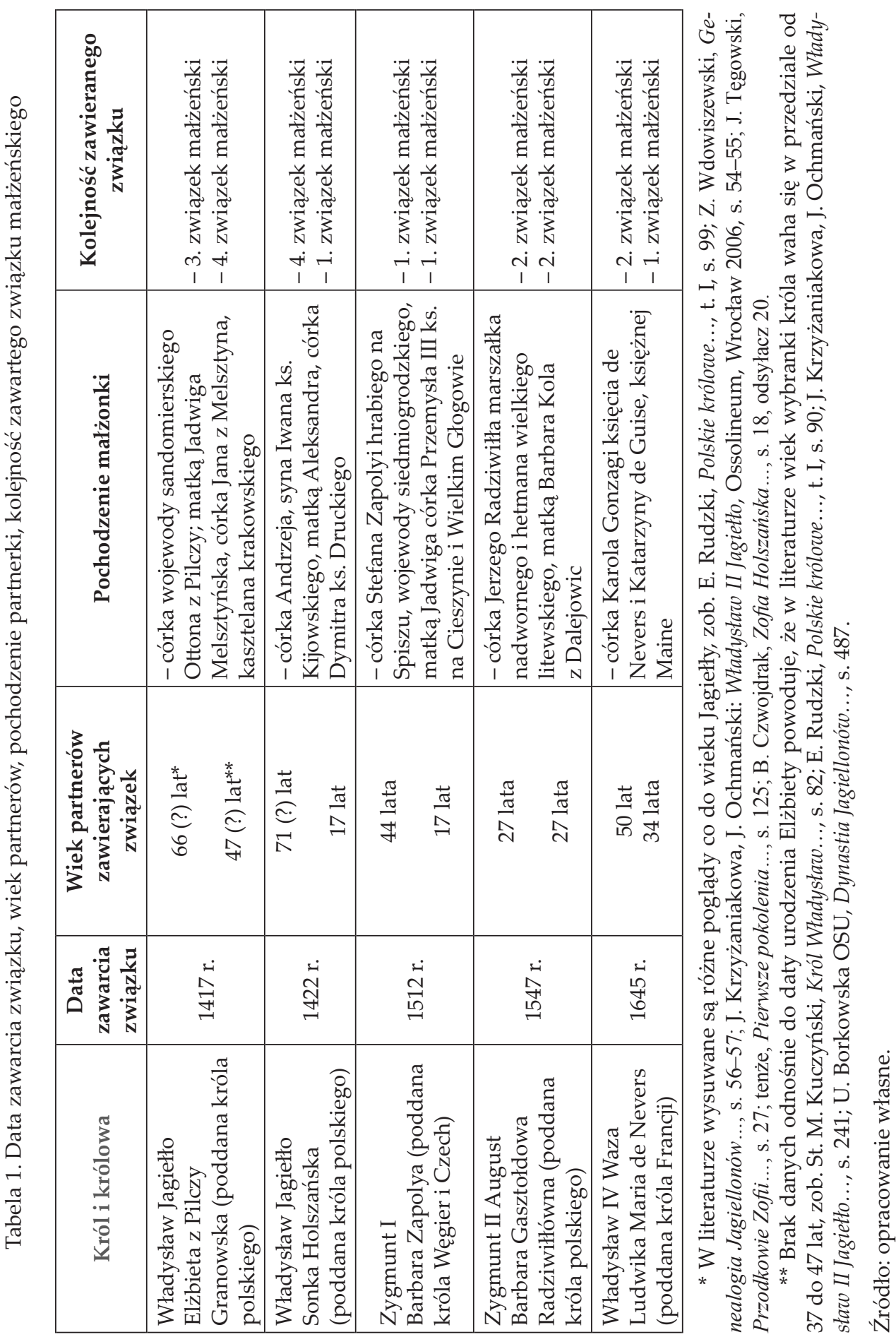




\section{Inicjator zawarcia związku}

O małżeństwie Władysława Jagieły z Elżbietą Granowską dowiadujemy się z Roczników Jana Długosza ${ }^{30}$. Zdaniem Juliana Bartoszewicza inicjatorem tego małżeństwa była przyjaciółka Elżbiety - księżna mazowiecka Aleksandra Olgierdówna, siostra króla Władysława II ${ }^{31}$. Inny pogląd wyraża Klemens Kantecki. Jego zdaniem monarcha posłużył się siostra, księżną Aleksandrą, aby pozyskać Elżbietę ${ }^{32}$, „do której [...] w przedziwny sposób pałał miłością"33. Była to decyzja samego króla, podjęta bez zasięgania opinii rady królewskiej ${ }^{34}$.

Według Ewy Maleczyńskiej małżeństwo Władysława II z Sonką zainicjował jej opiekun, książę Semen Dymitrowicz Drucki ${ }^{35}$. Część historyków przyjmuje, że pomysłodawcą poślubienia dużo młodszej od monarchy Sonki Olszańskiej był książę Witold ${ }^{36}$. Z kolei Bożena Czwojdrak uważa, że o poślubieniu Sonki zadecydował sam król, skorzystawszy z po-

30 Jana Długosza Roczniki czyli Kroniki Sławnego Królestwa Polskiego, księga jedenasta 1413-1430, red. i komentarz S. Gawęda, Warszawa 1985, s. 71-73.

31 "Król dat się opętać siostrze" w: Encyklopedyja powszechna, t. VIII, s. 248 s.v. Elżbieta, Helżbieta, z Pilczy (J. Bartoszewicz); podobnie A. Prochaska, Długosz o Elżbiecie..., s. 35; A. Strzelecka, Kobieta $w$ polityce dynastycznej i w życiu dworskim za panowania Władystawa Jagiełty (Drogi badań), [w:] Pamiętnik VI Powszechnego Zjazdu Historyków Polskich w Wilnie 17-20 września 1935 r., I Referaty, przygotował do druku F. Podhorecki, Lwów 1935, s. [7-8] 118-119; PSB, t. VI, Kraków 1948, s. 249 s.v. Elżbieta z Pilczy (Pilicy) Granowska (autor A. Strzelecka); Z. Wdowiszewski, Genealogia..., s. 73; M. Duczmal, Jagiellonowie. Leksykon biograficzny, WL, Kraków 1996, s. 227.

${ }^{32}$ K. Kantecki, Elżbieta trzecia żona Jagietly. Opowiadanie historyczne [Nadbitka z „Przeglądu Naukowego i Literackiego"], Lwów 1874, s. 52; St. M. Kuczyński, Król Władysław..., s. 81.

${ }^{33}$ Jana Długosza Roczniki czyli Kroniki..., s. 71.

${ }^{34}$ E. Maleczyńska, Rola polityczna królowej..., s. 23; E. Rudzki, Polskie królowe..., s. 9192; O. M. Przybyłowicz, Elżbieta Granowska: trzecia żona Władysława Jagiełty. Zycie codzienne królowej, „Kwartalnik Historii Kultury Materialnej” 1997, R. XLV, nr 1, s. 6; J. Tęgowski, Pierwsze pokolenie..., s. 129; M. R. Nitkiewicz, Królowa Elżbieta z Pilczy i Łańcuta trzecia żona Władysława Jagiełty, Łańcut 2003, s. 113; J. Krzyżaniakowa, J. Ochmański, Władysław II Jagiełło..., s. 242; J. Sperka, Elżbieta z Pilicy Granowska i król Władysław Jagiełło. Kulisy wielkiej miłości, [w:] Miłość w czasach dawnych, red. B. Możejko, A. Paner, Gdańsk 2009, s. 111-112; U. Borkowska OSU, Dynastia Jagiellonów..., s. 487.

${ }^{35}$ E. Maleczyńska, Rola polityczna królowej..., s. 24-25.

${ }^{36}$ St. M. Kuczyński, Król Władysław..., s. 85; J. Tęgowski, Przodkowie Zofii..., s. 27; tenże, Pierwsze pokolenie..., s. 129; Z. Wdowiszewski, Genealogia Jagiellonów..., s. 76; U. Borkowska OSU, Dynastia Jagiellonów..., s. 489; pogląd o tym, że wielki książę litewski Witold nakłonił Jagiełłę do małżeństwa z Sonką podaje Jan Długosz, Roczniki..., s. 165, a za nim Bernard Wapowski, Dzieje Korony Polskiej i Wielkiego Księstwa Litewskiego od roku 1380 do 1535 przez [...], wyd. M. Malinowski, t. I, Wilno 1847, s. 464-466. 
średnictwa księcia Witolda ${ }^{37}$. Próbę pogodzenia powyższych stanowisk zaproponowała Małgorzata Duczmal. Poznanie przez króla, względnie odnowienie znajomości z Sonką obudziło w nim nadzieję na potomstwo. Wykorzystał to książę Witold, poparty przez wuja dziewczyny Semena Druckiego namawiając Jagiełłę do małżeństwa ${ }^{38}$.

Literatura wypowiada się niejednoznacznie, kto był inicjatorem zawarcia małżeństwa Zygmunta I z Barbarą Zapolyą. Jodok L. Decjusz $\mathrm{w}$ kronice przedstawiającej m.in. pierwsze dziesięciolecie panowania Zygmunta I zapisał informację, że księżna cieszyńska Jadwiga, matka Barbary Zapolyi, zaczęła „na własną rękę zabiegać o przyszłe małżeństwo króla" ${ }^{\prime 39}$. Efektem tego było poselstwo w osobach księcia Kazimierza cieszyńskiego, brata księżnej Jadwigi, i archiprezbitera Budy Michała Hammela (Hamela, Hanela), posła króla Władysława węgierskiego, do Zygmunta I, które przybyło w listopadzie 1511 r. do Krakowa. Inne stanowisko $\mathrm{w}$ tej materii zaprezentował Julian Bartoszewicz. Zdaniem autora, inspiratorem związku był starszy brat Zygmunta I, Władysław, król Czech i Węgier, który „wyswatał to małżeństwo w r. 1512. Naprzód zwierzył się z tem matce (Barbary). Potem wyprawił poselstwo do Krakowa" $^{40}$. Pogląd ten znajduje potwierdzenie w Kronice Polskiej, Litewskiej, Żmudzkiej... Macieja Stryjkowskiego ${ }^{41}$. Zbliżone stanowisko zaprezentował Marian Dubiecki, który opierając się na Kronice Marcina Bielskiego przyjął, że była to decyzja Zygmunta I, podjęta za radą brata ${ }^{42}$. Inaczej za-

${ }^{37}$ B. Czwojdrak, Zofia Holszańska..., s. 17-19. Na rolę rodziny Sonki w wydaniu jej za mąż za Jagiełłę zwróciła uwagę A. Strzelecka, Kobieta w polityce dynastycznej..., s. 122.

${ }^{38}$ M. Duczmal, Jagiellonowie..., s. 423.

${ }^{39}$ Jodok L. Decjusz, Księga o czasach Zygmunta, Warszawa 1960, s. 55. O aktywnej polityce matrymonialnej prowadzonej przez Jadwigę Zapolya pisze Stanisław A. Sroka, Piastówny na Węgrzech w dobie Jagiellonów, [w:] Ecclesia Kultura Potestas. Studia z dziejów kultury $i$ społeczeństw, red. P. Krasa, A. Januszek, A. Zalewajek, W. Polak. Księga ofiarowana profesor Urszuli Borkowskiej OSU, Kraków 2006, s. 562.

${ }^{40}$ Zob.: Encyklopedyja powszechna, t. II, Warszawa 1860, s.v. Barbara Zapolska (autor: J. Bartoszewicz), podobnie Al. Przeździecki, Jagiellonki polskie w XVI wieku. Obrazy rodziny i dworu Zygmunta I. i Zygmunta Augusta Królów Polskich, t. I, Kraków 1868, s. 9.

${ }^{41}$ Kronika Polska, Litewska, Żmudzka i wszystkiej Rusi Macieja Stryjkowskiego..., poprzedzone wiadomością o życiu i pismach Stryjkowskiego przez Mikołaja Malinowskiego..., Warszawa 1846 , s. 364.

${ }^{42}$ "Lato 1512. Król Zygmunt za radą brata Władysława pojął sobie za żonę Barbarę...", Kronika Polska Marcina Bielskiego, ks. V, Warszawa 1830, s. 134, [w:] Zbiór Pisarzów Polskich, Część piąta, t. XVI, Warszawa 1830; M. Dubiecki, Przedstawicielki dawnych dynastyj. Zarys historyczny, [w:] tenże, Obrazy i studya historyczne, Serya II, Warszawa 1899, s. 202; J. Kieszkowski, Kanclerz Krzysztof Szydłowiecki. Z dziejów kultury i sztuki zygmuntowskich czasów, Poznań 1912, s. 178. Pogląd ten znajduje potwierdzenie w Commentarius zamieszczonym przez Stanisława Górskiego kanonika krakowskiego i płockiego w Acta Tomiciana, t. II, nr 1, s. 1 . 
gadnienie to ujmuje Aleksander Hirschberg, opierając się na Chronica Stanisława Górskiego zamieszczonej w Actach Tomiciana i niedrukowanych w Tomicianach tajnych instrukcjach wręczonych poselstwu Tomickiego ${ }^{43}$. Z myślą zawarcia małżeństwa wystąpił Zygmunt I, który z uwagi na to, że Barbara Zapolya była poddaną jego brata Władysława, króla Węgier, musiał uzyskać jego zgodę na ten związek ${ }^{44}$.

Kolejnym nie dynastycznym związkiem jest małżeństwo Zygmunta Augusta z Barbarą Radziwiłłówna, primo voto Gasztołdową. Michał Balicki, opierając się na Latopisie litewskim ${ }^{45}$, uważa, że decyzja została podjęta przez zakochanego Zygmunta Augusta, który złożył takie oświadczenie wobec jej rodzonego brata Mikołaja Radziwiłła Rudego i stryjecznego Mikołaja Radziwiłła Czarnego. Bracia zastali króla w odwiedzinach u Barbary, z która, według wcześniejszych ustaleń, miał się nie spotykać ${ }^{46}$. Zdaniem Witolda Ziembickiego do tej decyzji skłoniła go wiadomość o ciąży Gasztołdowej ${ }^{47}$. Odmienny pogląd wyraził Ludwik Kolankowski ${ }^{48}$. Król został "zniewolony" do poślubienia Barbary "salwując w ten sposób swoje królewskie słowo, że stosunki z Gasztołdową zerwie". Twórcami związku byli Radziwiłłowie ${ }^{49}$. Niejednoznaczne stanowisko zajął Zbi-

${ }^{43}$ Dr A. Hirschberg, O życiu i pismach Justa Ludwika Decjusza 1485-1545, Lwów 1874, s. 100 odsyłacz 3 [odbitka z "Przewodnika Naukowego i Literackiego"]. Na przekaz Ch. Engela, na którym opiera się Hirschberg, powołuje się również K. Baczkowski, Kongres Wiedeński 1515 roku, Oświęcim 2015, s. 76, odsyłacz 25.

${ }^{44}$ Dr A. Hirschberg, O życiu i pismach..., s. 100. Podobnie: PSB, t. I, s, 293, s.v. Barbara Zapola (autor W. Pociecha); E. Rudzki, Polskie Królowe..., s. 181; M. Duczmal, Jagiellonowie..., s. 137-138; M. Rekettyés, Stosunki polityczne..., s. 100; Ks. B. Przybyszewski, Barbara Zapolya Królowa Polski 1512-1515, Łańcut 2000, s. 22-23; J. Besala, Małżeństwa królewskie. Jagiellonowie, Warszawa 2006, s. 154; tenże, Zygmunt Stary i Bona Sforza, Poznań 2012, s. 176-177; K. Baczkowski, Kongres Wiedeński..., s. 76.

${ }^{45}$ M. Baliński, Pamiętniki o królowej Barbarze żonie Zygmunta Augusta, t. I, Warszawa 1837, s. 24, odsyłacz 1.

${ }^{46}$ Tamże, s. 25, 30-31; podobnie J. Bartoszewicz w: Encyklopedyja powszechna, t. II, s. 865-866 s.v. Barbara Radziwiłtówna; A. Przeździecki, Jagiellonki polskie..., s. 183-184; K. Szajnocha, O królach i bohaterach polskich. Opowiadania, Kraków 1892, s. 266-267; E. Kotłubaj powołując się na M. Balińskiego uważa, że decyzja o ślubie została powzięta wcześniej przez króla i Barbarę. E. Kotłubaj, Galerja Nieświeska portretów Radziwiłłowskich opisana przez [...] z drzeworytami M. Starkiewicza, czcionkami A. Marcinowskiego, Wilno 1857, s. 54, jednakże w M. Baliński, Pamiętniki o królowej Barbarze..., s. 38 nie znajdujemy potwierdzenia dla tej informacji.

${ }^{47}$ W. Ziembicki, Barbara Radziwitłówna w oświetleniu lekarskim, [w:] Pamiętnik VI Powszechnego Zjazdu Historyków Polskich w Wilnie..., s. 148; A. Sucheni-Grabowska, Zygmunt August..., s. 126; S. Cynarski, Zygmunt August, Wrocław-Warszawa-Kraków 2004, s. 50.

${ }^{48}$ L. Kolankowski, Zygmunt August, wielki ksiaże Litwy, do roku 1548, Lwów 1913, s. 340; Z. Wdowiszewski, Genealogia Jagiellonów..., s. 105.

${ }^{49}$ L. Kolankowski, Zygmunt August..., s. 341. 
gniew Kuchowicz. Z jednej strony uważa, że to Radziwiłłowie nakłonili Zygmunta Augusta do małżeństwa z Barbara z drugiej podkreśla, że królewicz był osobą, której nie można było do niczego zmusić, czyli że była to jego decyzja ${ }^{50}$. Ujęcie zawierające elementy powyższych wypowiedzi sformułował Józef Jasnowski. Zygmunt August powodowany uczuciem do Barbary, gdy nie dotrzymał obietnicy niekontaktowania się z nia, „, sam zdecydował się ostatecznie na ten krok" i obiecał małżeństwo Radziwiłłom. Tę obietnicę udało się Radziwiłłom wyegzekwować od młodego monarchy ${ }^{51}$. Nie towarzyszył temu żaden szantaż, tym niemniej Jasnowski przyjmuje, że dotrzymanie przez monarchę przyrzeczenia i poślubienie Barbary było w dużej mierze efektem energicznych zabiegów Mikołaja Czarnego Radziwiłła, którego także współcześni uważali za głównego sprawcę małżeństwa ${ }^{52}$.

Ostatnią nie dynastyczną partią było małżeństwo Władysława IV ${ }^{53}$ Wazy z Ludwiką Marią de Gonzaga. Z propozycjami matrymonialnymi wystąpił dwór francuski. Z przedstawionych przez posła francuskiego de Bregy kandydatek do zamążpójścia monarcha polski wybrał księżniczkę Ludwikę Marię de Gonzaga ${ }^{54}$.

\section{Reakcja społeczna na decyzję małżeńską monarchy}

Odpowiedź na pytanie, z kim monarcha zawrze związek małżeński, nie była obojętna dla rodziny królewskiej, jak i jego dworu czy szlacheckich poddanych. Ceną poparcia konkretnej kandydatki było oczekiwanie na przychylność z jej strony w dostępie do różnych form łaski królewskiej. Niebagatelną kwestią dla dynastii było zapewnienie następstwa

${ }^{50}$ Z. Kuchowicz, Barbara Radziwiłtówna..., s. 146-147.

${ }^{51}$ J. Jasnowski, Mikołaj Czarny Radziwiłt (1515-1565). Kanclerz i marszałek ziemski Wielkiego Księstwa Litewskiego, wojewoda wileński, Oświęcim 2014 (I wyd. 1939), s. 15, 16, 29.

${ }^{52}$ Tamże, s. 16.

${ }^{53}$ Pierwsza żona Cecylia Renata Habsburżanka zmarła 24 marca 1644 r.

${ }^{54}$ Na sejmie 1645 r.: „,Król też odezwał się do Rzplitey że się chce żenić, iż ma inklinacją do Maryey Ludoviki Karola Gonzagi Xiencia Mantuańskiego curki Xienżney Niwerneńskiey, w Królestwie Francuskim" zob. w: Pamiętniki do panowania Zygmunta III, Władysława IV i Jana Kazimierza z rkps. wydał K. Wł. Wójcicki, Warszawa 1846, s. 263; W. Konopczyński, Dzieje Polski Nowożytnej, t. I, Warszawa 1986, s. 271; M. Serwański, Francja wobec Polski w dobie wojny trzydziestoletniej (1618-1648), Poznań 1986, s. 328. Kardynał Richelieu już wcześniej zgłaszał kandydaturę tej księżniczki „w małżeństwo” Władysławowi IV, lecz senat w lutym 1637 r. odrzucił projekt francuskiego małżeństwa, zob. A. S. Radziwiłł, Pamiętniki o dziejach w Polsce, t. II, 1637-1646, przekład i opracowanie A. Przyboś, R. Żelewski, Warszawa 1980, s. 16-17. 
tronu, jak również uzyskanie korzyści politycznych wynikających z zacieśnienia przy tej okazji związków między państwami. Krytyka wybranek królewskich skupiła się na trzech elementach: niskim pochodzeniu stanowym kobiety, obawie, że nie zostanie spełniony cel prokreacji oraz skutkach politycznych wynikających z tego związku dla państwa.

\subsection{Nierówność stanowa}

Oddźwięk, jaki wywołał związek Jagiełły z Elżbietą Granowską odnotowany został w Satyrze na małżeństwo Władysława Jagiełty z Elżbieta Granowska autorstwa Stanisława Ciołka, sekretarza kancelarii królewskiej ${ }^{55}$ i w późniejszych o prawie pół wieku Rocznikach Jana Długosza. Obaj pisarze podkreślają niższość stanową małżonki króla. S. Ciołek zwraca uwagę na skutki płynące z takiego aktu, "gdyby ożeniono go [króla] z jego poddana, $[. .$.$] nie tylko upodliłby się wspaniały majestat, ale i całe potom-$ stwo nosiłoby piętno zbyt różniących się od siebie rodziców". Małżeństwo „niżej stojącej kobiety [...] z godniejszymi mężami” nie prowadzi do równości stanowej tejże kobiety ${ }^{56}$. Cierpi na tym autorytet władcy ${ }^{57}$. Decyzja monarchy o zamiarze małżeństwa z Granowską spotkała się więc ze sprzeciwem rady królewskiej5. Nie pochwalał jej książę Witold. „Mimo sprzeciwów i perswazji niemal wszystkich prałatów i panów Królestwa Polskiego, szczególnie [...] wojewody poznańskiego Sędziwoja Ostroroga" monarcha postawił na swoimi, Elżbieta została koronowana ${ }^{59}$.

${ }^{55}$ S. Ciołek, Satyra na małżeństwo Władysława Jagiełty z Elżbieta Granowska, [w:] Toć jest dziwne a nowe. Antologia literatury polskiej średniowiecza, oprac. A. Jelicz, Warszawa 1987, s. 272-276. Satyra została napisana w latach 1417-1419.

${ }^{56}$ S. Ciołek, Satyra na małżeństwo Władysława..., s. 273. Opinię o „nierównym i nieprzyzwoitym małżeństwie” króla powtórzyli: Jan Długosz, Roczniki czyli Kroniki..., s. 72, 73; Bernard Wapowski, Dzieje Korony Polskiej i Wielkiego Księstwa Litewskiego..., s. 392.

${ }^{57}$ „Nie wstyd mu [królowi] było, że przez ten upragniony z tą kobietą związek osłabił osiągającą mnóstwo pomyślnych wyników władzę królewską i że smutnymi namiętnościami doprowadził do jej załamania się. Im bowiem większym uznaniem cieszył się król, tym szpetniejszy był dla niego tego rodzaju związek, który i u obcych, i u swoich podważył sławę króla" zob. Jana Długosza Roczniki czyli Kroniki..., s. 72; podobnie S. Ciołek, Satyra na małżénstwo Władysława..., s. 273-274.

58 Jana Długosza Roczniki czyli Kroniki..., s. 73.

${ }^{59}$ Tamże, s. 76-77. Według Bernarda Wapowskiego „Sędziwój z Ostroroga z wielu innymi panami żwawo opierał się, aby niegodna takiego stopnia, koronowaną być miała". B. Wapowski, Dzieje Korony Polskiej i Wielkiego Księstwa Litewskiego..., s. 392; zob. Rozbiór krytyczny Annalium Poloniae Jana Dtugosz z lat 1385-1444, t. I, oprac. St. Gawęda, K. Sieradzka, J. Radziszewska, K. Stachowska pod kierunkiem J. Dąbrowskiego, Wrocław-Warszawa-Kraków 1961, s. 171. 
Na nierówność stanowa, która wystąpiła przy czwartym małżeństwie Jagiełły, wskazuje Długosz używając określenia, że był to związek „między nierównymi partnerami"60. Nie podaje jednak w swoim dziele, czy wspomniany fakt wywołał sprzeciw otoczenia monarchy.

Opinię o zróżnicowanej ocenie ówczesnych "Polaków i Węgrów" na wybór małżonki przez Zygmunta I w osobie Barbary Zapolyi zanotował Marcin Bielski ${ }^{61}$. Przeciwnicy związku wytykali nierówne pochodzenie rodu Zapolyów, inni natomiast podkreślali jego „cnotę i sławę”.

Wieść o potajemnym poślubieniu przez Zygmunta Augusta Barbary Radziwiłłównej, wywołała wzburzenie opinii szlacheckiej. Stanisław Orzechowski pisząc o Barbarze stwierdzał, że zdaniem posłów „żona nie była królowi równą [...] że białogłowa lubo prawda wysoko urodzona i wielkiego pokrewieństwa w Litwie, będąc jednak podległa królowi, równego wspaniałości królewskiej przynieść nie mogła pokrewieństwa"62. $\mathrm{Z}$ tych samych przyczyn decyzja monarchy nie spotkała się $\mathrm{z}$ aprobatą rady wielkoksiążęcej w Wilnie w kwietniu 1548 r. ${ }^{63}$ Królowa Bona, która nie akceptowała pierwszego małżeństwa swego syna z Habsburżanka, jak stwierdza S. Cynarski, nie mogła się pogodzić z tym, że Gasztołdowa będzie jej synową ${ }^{64}$. Na pierwszym sejmie koronnym w Piotrkowie, zwołanym po śmierci Zygmunta I Starego, doszło do wystąpień skierowanych przeciw małżeństwu królewskiemu. W wystąpieniu sejmowym Piotr Boratyński argumentował między innymi, że "małżeństwo [...] między nierównymi, to jest miedzy panem i poddana, między pomazańcem bożym a wdowa, nie poszło z Boga" ${ }^{\prime 65}$. Szlachta uważała ślub

${ }^{60}$ Jana Długosza Roczniki czyli Kroniki..., s. 166.

${ }^{61}$ Kronika polska Marcina Bielskiego, t. II (księga IV-V), wydanie Kazimierza Józefa Turowskiego, Sanok 1856, s. 962; za nim G. Lengnich, Prawo pospolite Królestwa Polskiego..., t. I, Kraków 1761, s. 525.

${ }^{62}$ Kroniki Stanisława Orzechowskiego, tłum. z łacińskiego M. Z. Al. Włyński, wyd. K. J. Turowski, Sanok 1856, s. 26-27.

${ }^{63}, \ldots[. .$.$] khdy to usłyszali i dowiedali pewnosty, Panowie rada Welikoho Kniażestwa,$ iż Korol z toju Paniejeu potajemnie szlub brał, i serdecznie toho żałowali, i poczali upominaty i prosity Korola slezno aby toho ne czynił i nierowny sobie, Poddanoje swojeje za małżonku nie brał potom wsim ludiem, i wsiej ziemli, toje ożenienie Korolewskoje było welmi niemiło, a mnogie tomu wiery dopustity niechotieli, i mnogie paszkwili pisali o tom [...]", T. Narbutt, Pomniki do Dziejów Litewskich pod względem historycznym, dyplomatycznym, geograficznym itp. [...] zebrane przez [...], Wilno 1846, s. 79-80.

${ }^{64}$ S. Cynarski, Zygmunt August, Wrocław-Warszawa-Kraków 2004, s. 52.

65 Ł. Górnicki, Dzieje w Koronie Polskiej, oprac. H. Barycz, Wrocław 2003, s. 27, zob. s. 26, 28, 29. 
zawarty potajemnie, bez zasięgnięcia opinii senatu za "szkodliwy"66. W trakcie dyskusji starosta generalny wielkopolski Andrzej Górka, występując w imieniu całej rady królewskiej i stanu szlacheckiego przeciwko małżeństwu Zygmunta, powołując się na prawo zwyczajowe, stwierdzał: „iście to małżeństwo WKMci z poddaną złączone teraz nie ma: a iż się też za tem małżeństwem powiada o przyochędożeniu nizkiego stanu tej tam małżonki WKMci wysokim stanem królewskim, toć każdy najj. Miłościwy Królu przyznawać musi, iżeś WKM. zacnością swą okrasić raczył tej to paniej, aleś WKM [...] stan osoby swej królewskiej, tudzież poddanych swych niepomału poniżyć raczył, pojąwszy WKM. poddaną swą a zwłaszcza takowej familii i z takowego ludu wziąwszy małżonkę, którzy dopiero od półtora sta lat ex summa et inculta barbarie wiarę prawdziwą chrześciańską uznali i w tymże też krótkim wieku stan rycerski i herby od nas Polaków dopiero przyjęli" ${ }^{\prime 67}$. A. Górka wskazując na niskie pochodzenie wybranki monarszej stwierdzał, że „poddana” przez małżeństwo z monarchą nie pozbywa się dawnej przynależności stanowej. Podkreślał zarazem niedawne dopiero przyjęcie przez jej ród wiary chrześcijańskiej i wejścia w szeregi szlachty ${ }^{68}$. Monarcha odrzucił żądanie unieważnienia związku powołując się na nierozerwalność małżeńskiego sakramentu ${ }^{69}$.

Sprawa pochodzenia wybranki królewskiej wyniknęła w trakcie obrad senatu w roku 1635. Na posiedzeniu Władysław IV wystąpił o rozważenie wniosku ożenku monarchy z Polką nie podając kogo miał na myśli. Zdania senatorów były podzielone. „[O]bawiano się żeby ten honor zpowinowacenia się z Krulem Adwersarzowi iego nie dostał się, a przez kolligacią żeby w gurę Krul niewynios"70. Zwolennicy monarchy, przywołując małżeństwa Jagiełły z Granowską i Holszańską, jak i Zygmunta II Augusta z Radziwiłłówna, argumentowali, że Rzeczypospolita $\mathrm{z}$ tego tytułu nie poniosła żadnej szkody. Władysław IV pojął ostatecznie za żonę Cecylię Renatę Habsburg. Po jej śmierci król powziął zamiar zawarcia małżeństwa z Ludwiką Marią de Nevers, poddaną króla Francji, co spotkało się z krytyką ${ }^{71}$. Kwestia ta była przedmiotem roko-

\footnotetext{
${ }^{66}$ M. Ferenc, Mikołaj Radziwiłł „Rudy” (Ok. 1515-1584). Działalność polityczna i wojskowa, Kraków 2008, s. 94.

${ }^{67}$ Dyaryusz sejmu piotrkowskiego 1548, [w:] Dyaryusze sejmów koronnych 1548, 1553 i 1570 z rkp. wyd. J. Szujski, Kraków 1872, s. 204.

${ }^{68}$ Dyaryusz sejmu piotrkowskiego $1548 \ldots$... s. 204; chrystianizację Litwy rozpoczęto w roku 1386. Gasztołdowie, jako ród bojarski wyznania rzymskokatolickiego postanowieniem unii horodelskiej zostali przyjęci do polskiego rodu herbowego Abdank.

${ }^{69}$ Zob. wypowiedzi Zygmunta Augusta, Dyaryusz sejmu piotrkowskiego 1548..., s. $177-178,182-183$.

${ }^{70}$ Pamiętniki do panowania Zygmunta III, Władysława IV..., s. 237.

${ }^{71}$ M. Serwański, Francja wobec Polski..., s. 343.
} 
wań pomiędzy posłem francuskim Nicolas de Flécelles hrabią de Brégy a kanclerzem wielkim koronnym Jerzym Ossolińskim ${ }^{72}$. Na wniosek Władysława IV, strona polska - ze względu na powagę polskiego monarchy - żądała, aby Francja oficjalnie traktowała Ludwikę Marię jako równą francuskim księżniczkom $\mathrm{krwi}^{73}$. Postanowienie to zamieszczono w układzie prowizorycznym podpisanym 17 lipca 1645 r. w Warszawie ${ }^{74}$. Uzgodniono, że małżeństwo Władysława IV z Ludwiką Marią jest równe znaczeniem mariażowi z francuską księżniczką krwi. Postanowienie powyższe znalazło potwierdzenie $w$ intercyzie małżeńskiej zawartej 26 września 1645 r. w Fontainebleau ${ }^{75}$. W pamiętniku Albrecht Stanisław Radziwiłł, kanclerz wielki litewski, odnotował, że Ludwika Maria „przed zamążpójściem została dekretem ogłoszona córką Królestwa Francji"76. Aktem tym wprowadzono Ludwikę Marię do rodziny królewskiej. Uznanie Ludwiki Marii za królewską córę Francji sytuowało ją wysoko w hierarchii społecznej. Tytuł Madame de France przysługiwał tylko córce króla. W wyniku negocjacji status społeczny Ludwiki Marii uległ zmianie, jako że stała się członkiem dynastii panującej, co sprawiło, że małżeństwo jej z królem Polski przestało być niedynastyczne. Był to wyjątek.

\section{4.2. Cel prokreacji}

Sprawa posiadania prawowitego męskiego dziedzica była dla panującego, jak i jego otoczenia, problemem najwyższej wagi. Obawy o potomstwo zostały wysunięte wobec dwóch z pięciu omawianych związków, mianowicie wobec Elżbiety Granowskiej i Ludwiki Marii. Obawy dworu o możliwość posiadania przez Jagiełłę potomka, związane z jego wiekiem, wyraził Stanisław Ciołek w Satyrze na małżeństwo... Autor pisał: „lękamy się przeciągać poszukiwania, by tymczasem [król] nie utracił siły męskiej czy nie dokonał żywota wcześniej, nim nas poszerzy spło-

${ }^{72}$ Dr. L. Kubala, Jerzy Ossoliński, t. I, Lwów 1883, s. 250, 308.

${ }^{73}$ W. Czapliński, Władysław IV wobec wojny 30-letniej (1637-1645), Kraków 1937, s. 110; M. Serwański, Francja wobec Polski..., s. 343-344.

${ }^{74}$ XX. Point consentis entre le sieur Brégy de Flécelles et le Sénateurs de Polotne pour le mariaże de la Princesce; Warszawa 17 lipca, pkt 1, [w:] K. Waliszewski, Polsko-francuskie..., s. 201.

${ }^{75}$ Pacta matrimonialia Inter Vladislaum IV. Regem Poloniae ac Ludovicam Mariam Gonzagam, Ludovici XIV Regis Galitae, [w:] M. Dogiel, Codex diplomaticus Regni Poloniae et Magni Ducatus Lithuaniae, t. I, cz. 1-2, Vilno 1758, s. 469-473.

${ }^{76}$ A. S. Radziwiłł, Pamiętnik o dziejach w Polsce, t. II, 1637-1646, przekł. i oprac. A. Przyboś, R. Żelewski, Warszawa 1980, s. 456. Z. Wdowiszewski odsyła do S. A. Radziwiłł, Pamiętniki, wyd. E. Raczyński, Poznań 1839, s. 175. 
dzeniem potomka, bo już bardzo posunął się w latach"77. Krytycznie wypowiedział się o Elżbiecie, małżonce króla. Uważał, że była ona osobą „wyjałowioną wieloma połogami, niezdolną do rodzenia, bo strawiła się w poprzednich związkach"78. Granowska była wdową po trzech mężach, z trzeciego związku dochowała się dwóch córek i dwóch synów ${ }^{79}$. Odmienny pogląd wyrazili Antoni Prochaska i Stanisław M. Kuczyński. Fakt, ze Elżbieta była matką czworga dzieci pozwalał monarsze sądzić, że może mieć z nią potomstwo ${ }^{80}$. Zdaniem Stanisława Ciołka potomstwo ze związku nierównego stanowo „upodliłoby” królewski majestat i „nosiłoby piętno zbyt różniących się od siebie rodziców" ${ }^{\prime 1}$. Granowska nie dała królowi potomka.

W stosunku do Sonki Holszańskiej i Barbary Zapolyi w źródłach nie znajdujemy informacji o obawach, co do zapewnienia potomstwa dynastii $^{82}$. Sonka i Barbara były w tym samym wieku, liczyły po siedemnaście lat. Sonka dała Jagielle dwóch synów, ze związku z Barbarą Zapolyą Zygmunt I miał dwie córki ${ }^{83}$.

Barbara Gasztołdowa była od wyżej wymienionych królowych o dziesięć lat starsza ${ }^{84}$. Sprzeciw szlachecki, do którego doszło na wieść o jej potajemnym małżeństwie z królem Zygmuntem II Augustem, wywołał inne obawy. Jak pisał Ludwik Kolankowski, opierając się na relacjach posłów gdańskich z obrad sejm 1548 r., opozycja wysunęła wówczas postulat, że może uznać małżeństwo pod warunkiem, że przyszli potomkowie króla z Barbarą nie mieliby żadnych praw dziedzicznych na Litwie ${ }^{85}$. Jan

77 S. Ciołek, Satyra na małżeństwo..., s. 274

${ }^{78}$ Tamże, s. 275; opinię tę powtórzyli J. Długosz, Roczniki..., s. 71-72; B. Wapowski, Dzieje Korony Polskiej..., s. 390-391.

${ }^{79}$ PSB, t. VI, s. 249, s.v. Elżbieta z Pilcy (Pilicy) Granowska [autor Anna Strzelecka]; O. M. Przybyłowicz, Elżbieta Granowska: trzecia żona Władysława..., s. 4.

${ }^{80}$ A. Prochaska, Długosz o Elżbiecie..., s. 35-36; St. M. Kuczyński, Król Jagiełto..., s. 82.

${ }^{81}$ S. Ciołek, Satyra na małżeństwo..., s. 273.

${ }^{82}$ Antoni Prochaska powołując się na rocznik szamotulski podaje, że Sonkę król pojął za żonę za poradą swych lekarzy, gdyż była młoda i zdrowa, a król był żądny potomków, tenże, Dtugosz o Elżbiecie..., s. 35; zob. też E. Maleczyńska, Rola polityczna królowej Zofii..., s. 34-35. Podobną informacje odnoszącą się do Barbary Zapolyi podaje Jodok L. Decjusz: „Już wtedy było wiadomo, że [król - T.S.] szuka sobie małżonki i królowej, aby po jego śmierci Królestwo nie dostało się w obce ręce" w: Księga o czasach Zygmunta..., s. 40.

${ }^{83}$ A. Przeździecki, Jagiellonki polskie..., s. 14, 28; Ks. B. Przybyszewski, Barbara Zapolya Królowa..., s. 69.

${ }^{84} \mathrm{O}$ wieku Barbary zob. Z. Kuchowicz, Barbara Radziwiłtówna..., s. 51-54.

${ }^{85}$ L. Kolankowski, Zygmunt August, wielki ksiażę..., s. 345; za nim Wł. Bogatyński, Z dziejów małżeństwa Zygmunta Augusta z Barbara, RAU WH-F Serya II, t. XXXIV, Kraków 1916, s. 196; zob. Dyaryusz sejmu piotrkowskiego 1548 ..., s. 215, wypowiedź Andrzeja Górki, starosty generalnego Wielkopolski. 
Sierakowski, marszałek izby poselskiej, w wystąpieniu do senatu mówił: „[...] żądamy, aby to małżeństwo się odmieniło, a z inszej sobie równej małżonki JKM. Pan nasz płód swego świętego a chwalebnego narodu [rodu - uwaga wydawcy] ku pociesze po sobie ostawić raczył" ${ }^{\prime \prime 6}$. Barbara zeszła bezpotomnie.

Pod adresem Ludwiki Marii Gonzagi wysuwano zastrzeżenia, że może nie mieć dzieci. Opinię, że podobno jest ona bezpłodna, wyraził ks. Maksymilian v. Dietrichstein, poseł cesarski na audiencji u Władysława IV, jeszcze przed dojściem małżeństwa do skutku ${ }^{87}$. Z kolei wątpliwość co do uzyskania potomstwa przez samego króla wyraził jeden z senatorów. Zdarzyło się to w trakcie tajnego posiedzenia senatu, na którym wyrażono zgodę na małżeństwo monarchy ${ }^{88}$. Powodem tego była zbyt duża otyłość władcy. Władysław IV nie miał potomstwa z Ludwiką Marią.

\subsection{Skutki polityczne wynikające z zawartego związku}

Po śmierci królowej Anny Cylejskiej (1416 r.) król Władysław nosił się z myślą zawarcia związku z księżną Brabantu, Elżbieta, bratanicą Zygmunta Luksemburczyka, króla Węgier, lecz ta odrzuciła matrymonialną 258 propozycję ${ }^{89}$. Jagiełło, nim jeszcze dotarła do niego odpowiedź, podjął decyzję o ślubie z Granowską ${ }^{90}$. Długosz, pod wpływem Zbigniewa Oleśnickiego, niechętnie nastawiony był do Granowskiej. Z perspektywy czasu o skutkach tego kroku pisał: „,[król] przez ten związek osłabił osiągającą mnóstwo pomyślnych wyników władzę królewską i że smutnymi namiętnościami doprowadził do jej załamania się. [...] król Władysław mógł był bardziej odpowiednie małżeństwo zapewnić sobie i swoim księstwom ogromne korzyści i odszkodowanie ${ }^{\prime \prime 1}$. Wiadomość o tym małżeństwie, zdaniem autora Roczników, wykorzystali Krzyżacy do zniesławienia monarchy na soborze w Konstancji i wobec Zygmunta Luksemburczyka ${ }^{92}$. Po śmierci Elżbiety nowe małżeństwo dla Jagiełły było koniecznością: monarcha potrzebował następcy. Planowano małżeństwo z Elżbietą jedyną córką Zygmunta Luksemburskiego, króla Węgier, względnie z Ofką, jego

${ }^{86}$ Dyaryusz sejmu piotrkowskiego 1548..., s. 209.

${ }^{87}$ W. Czapliński, Władysław IV wobec wojny 30-letniej..., s. 100.

88 , $[. .$.$] senat zgodził się, by król mógł ponowić śluby małżeńskie. Nie należy prze-$ milczeć powiedzenia jednego senatora w związku z ożenkiem: król jest otyły, więc nie jest pewne, czy otyłość nie przeszkodzi w dopełnieniu małżeństwa. [król] przyjął wypowiedź niewesołym obliczem"; A. S. Radziwiłł, Pamiętnik o dziejach..., t. II, s. 443.

${ }^{89}$ Z. Wdowiszewski, Genealogia Jagiellonów..., s. 69.

${ }^{90}$ M. Duczmal, Jagiellonowie..., s. 226.

${ }^{91}$ Jana Długosza Roczniki czyli Kroniki..., s. 72, 73.

${ }^{92}$ Tamże, s. 74. 
bratowa, wdową po królu Czech Wacławie. Z ofertą matrymonialną łączyła się ekspektatywa uzyskania przez Polskę Śląska po śmierci Zygmunta Luksemburskiego, który nie miał potomstwa ${ }^{93}$. W przypadku wzięcia za żonę wdowy po bracie Wacławie, Zygmunt Luksemburczyk przyrzekał ponadto "tytułem posagu zapisać jej [...] sto tysięcy florenów”. W radzie królewskiej wysunięto również projekt swatania monarchy z córką księcia moskiewskiego. Z małżeństwem z Luksemburżanką członkowie rady łączyli ogromne korzyści i nadzwyczajne zyski, „które miały spłynąć na Królestwo Polskie [...] przez zapis ziem śląskich" ${ }^{\prime 94}$. W tej sytuacji decyzja królewska mogła budzić sprzeciw. Małżeństwo z Sonką niweczyło ich oczekiwania.

Od zawarcia związku matrymonialnego Zygmunta I z Barbarą Zapolya, jak przekazuje Jodok L. Decjusz „wzięła [...] początek nienawiść ze strony Cesarza Maksymiliana" ${ }^{25}$. Odrzucenie oferty matrymonialnej wysuniętej przez cesarza Maksymiliana, celem pokrzyżowania związku Zygmunta I z Barbara, Stanisław Górski skomentował następująco: „było nie do smaku Maxymilianowi, który odtąd niechęć ku Zygmuntowi powziął i przeciw niemu Krzyżaków pruskich i Mistrza ich Alberta Margrabi Brandenburskiego poduszczać począł i z W. X. Moskiewskim wziął przymierze dla toczenia wojny przeciw Zygmuntowi"96. Tymczasem antyjagiellońskie nastawienie polityki Maksymiliana I nie wzięło swego początku od zacieśnienia związków Zygmunta I z Zapolyanka, lecz było kontynuacją polityki cesarza prowadzonej już przed rokiem $1511^{97}$. Małżeństwo Jagiellona z Barbarą uderzało w plany dynastii habsburskiej zmierzającej do zawładnięcia koroną węgierską̨ . W trakcie uroczystości weselnych w Krakowie zawarto tajne przymierze. Zygmunt I Jagiellończyk brał ród Zapolyiów z ich majątkami i prawami „pod naszą specjalną opiekę i protekcje, obiecując im i ofiarując przeciw wszystkim ich przeciwnikom i rywalom pomoc,

${ }_{93}$ Tamże, s. 158, za Długoszem K. Kantecki, Elżbieta trzecia żona Jagiełty..., s. 53-54; A. Prochaska, Długosz o Elżbiecie..., s. 40.

${ }^{94}$ Jana Długosza Roczniki czyli Kroniki..., s. 165; Rozbiór krytyczny Annalium Poloniae..., s. 193-192; J. Krzyżaniakowa, J. Ochmański, Władysław II Jagiełło..., s. 271.

${ }^{95}$ Jodok L. Decjusz, Księga o czasach Zygmunta..., s. 56.

${ }^{96}$ M. Wiszniewski, Pomniki historyi i literatury Polskiey, t. IV, Kraków 1837, s. 119; Acta Tomiciana (dalej: AT), t. II, 1 Commentarius, s. 1; Kronika Marcina Bielskiego, t. II (księga IV, V), wyd. Kazimierza J. Turowskiego, Sanok 1856, s. 963.

${ }^{97}$ W. Konopczyński, Dzieje Polski Nowożytnej, t. I, Warszawa 1986, s. 74-75; K. Baczkowski, Państwo polsko-litewskie w koncepcjach Maksymiliana I, [w:] tenże, Polska i jej sąsiedzi za Jagiellonów, Kraków 2012, s. 551-554.

${ }_{98}$ W. Felczak, Historia Wegier, Wrocław-Warszawa-Kraków 1966, s. 105-106, 114; Historia dyplomacji polskiej, t. I, Połowa X w. - 1572, red. M. Biskup, Warszawa 1982, s. 616-617, 621. 
radę i według sił obronę"99. Związek matrymonialny Zygmunta z Barbarą wzmacniał pozycję obozu narodowego z Zapolyami na czele wobec stronnictwa prohabsburskiego na Węgrzech ${ }^{100}$.

Potajemne małżeństwo Zygmunta II Augusta z jego poddaną, Barbarą Gasztołdowa, wywołało ogromne sprzeciwy ${ }^{101}$. Po pogrzebie starego króla na sejmie w Piotrkowie „z wielką usilnością domagali się posłowie, aby przez sejm owo spełzło małżeństwo, że i żona nie była królowi równą i żadnej z sobą nie przynosiła korzyści". Stanisław Orzechowski argumentował, że Polakom potrzebne jest małżeństwo „[...] któreby ich w nieszczęściu pieniędzmi zapomódz i nowem pokrewieństwem zaszczycić mogło"102. Warunków tych nie spełniało małżeństwo z Gasztołdową. Monarcha mając niewielkie poparcie, będąc w obliczu potężnej opozycji, na czele której stała jego matka, królowa Bona, zmuszony był podjąć kroki celem osłabienia tejże opozycji domagającej się unieważnienia związku ${ }^{103}$. Przekupstwa jednak nie zmieniły nastrojów wśród szlachty. Spór o małżeństwo króla groził rokoszem szlacheckim. Aby zabezpieczyć się przed tym niebezpieczeństwem, Zygmunt II August zawarł z królem rzymskim Ferdynandem Habsburgiem traktat zawierający przyrzeczenie „każdej ze stron, iż nie udzieli ona poparcia ewentualnym próbom buntu przeciw sojusznikowi podnoszonym w jego własnym kraju"104, lecz okaże pomoc przeciw takim poddanym ${ }^{105} \mathrm{~W}$ zakresie wskazanym przez kontrahenta ${ }^{106}$.

W trakcie rokowań nad warunkami zawarcia małżeństwa między Władysławem IV a Ludwiką Marią de Gonzaga zagadnienia polityczne, co podkreśla literatura, zeszły na plan dalszy. Strona polska nacisk położyła na korzyści materialne ${ }^{107}$. Władysław Czapliński stwierdził, że

${ }^{99}$ Cyt. za K. Baczkowski, Kongres wiedeński..., s. 85; tenże, Stosunki między elitami władzy Polski i Wegier na przełomie XV i XVI wieku, [w:] tenże, Polska i jej sąsiedzi..., s. 533.

${ }^{100}$ K. Liske, Kongres Wiedeński roku 1515, [w:] tenże, Studia z dziejów wieku XVI, Poznań 1867, s. 15.

${ }^{101}$ M. Ferenc, Mikołaj Radziwiłt „Rudy”..., s. 67, 74, 94, 96.

${ }^{102}$ Kroniki Stanisława Orzechowskiego..., s. 26-27.

${ }^{103}$ J. Janowski, Mikołaj Czarny Radziwiłt..., s. 20-22, 29, 34, 40.

${ }^{104}$ A. Sucheni-Grabowska, Zygmunt August..., s. 202.

${ }^{105}$ Wł. Bogatyński, Z dziejów małżeństwa Zygmunta Augusta..., s. 200-201; T. Szulc, Historiograficzny bilans polityki ostatniego z Jagiellonów, „Studia z Dziejów Państwa i Prawa Polskiego", t. II, red. J. Matuszewski, [Łódź] 1995, s. 113; J. Jasnowski, Mikołaj Czarny Radziwiłł..., s. 52. Zdaniem A. Sucheni-Grabowskiej intencją króla polskiego było to, aby „związać ręce kontrahentowi i uniemożliwić [...] wyciągnięcie dla siebie korzyści z rozterek wewnątrzpolitycznych w Polsce", zob. A. Sucheni-Grabowska, Zygmunt August..., s. 202.

${ }^{106}$ A. Sucheni-Grabowska, Zygmunt August..., s. 204.

${ }^{107}$ K. Waliszewski, Polsko-francuskie..., s. 14-15; W. Czapliński, Władysław IV wobec wojny 30-letniej..., s. 109-111; M. Serwański, Francja wobec Polski..., s. 342, 343, 346-347, 349. 
„[d]la króla małżeństwo stawało się układem o znaczeniu finansowym”108. Obietnice złożone na rzecz Władysława IV podczas negocjacji przez posła francuskiego były tak korzystne, że dwór francuski obawiał się, że „prędzej czy później [...] wypadnie dołożyć ze skarbu Jej arcy-chrześcijańskiej mości z jakie 1200000 liwrów"109.

\section{Okoliczności zawarcia małżeństwa}

Trzy spośród wymienionych wcześniej pięciu żon królewskich były poddanymi polskiego monarchy. Były to Elżbieta Granowska, Sonka Holszańska i Barbara Gasztołdowa Radziwiłłówna. Barbara Zapolya i Ludwika Maria de Gonzaga były poddanymi obcych władców, pierwsza króla Węgier, druga króla Francji.

Z Satyry na małżeństwo Władystawa Jagietly z Elżbieta Granowska Stanisława Ciołka wynika, że związek poprzedziły rozmowy króla z Elżbietą i zasięgnięcie przez Jagiełłę rady u księcia Witolda ${ }^{110}$. Jan Długosz napisał w Kronikach, że „podobno zawarto to małżeństwo podczas odbytych [...] tajemnych układów" ${ }^{\prime 111}$. Decyzję o zamiarze poślubienia Elżbiety ogłosił władca niespodziewanie 1 maja 1417 r. na zjeździe panów rady królewskiej w Sanoku. Następnego dnia, w miejscowym kościele parafialnym, arcybiskup lwowski Jan Rzeszowski udzielił młodej parze sakramentu małżeństwa ${ }^{112}$. Matka królowej, Jadwiga z Melsztyna, była matką chrzestną Jagiełły. Tym samym król i Elżbieta w świetle prawa kościelnego byli tzw. rodzeństwem duchowym, co było przeszkodą uniemożliwiającą zawarcie małżeństwa. Celem usunięcia tej przeszkody, „by mu wolno było pozostać w małżeństwie, które zawarł z Elżbietą", monarcha przed koronacją swej małżonki wystarał się przez wysłannika na soborze w Konstancji o dyspensę $e^{113}$. Koronacja Elżbiety odbyła się 19 listopada 1417 r. w katedrze krakowskiej ${ }^{114}$.

${ }^{108}$ W. Czapliński, Władysław IV wobec wojny 30-letniej..., s. 111.

${ }^{109}$ Cyt. za K. Waliszewski, Polsko-francuskie..., s. 16.

110 S. Ciołek, Satyra na małżeństwo Władystawa..., s. 276; Jana Długosza Roczniki..., s. 73; E. Rudzki, Polskie królowe..., s. 92; M. Duczmal, Jagiellonowie..., s. 227.

${ }^{111}$ Jana Długosza Roczniki czyli Kroniki..., s. 72.

${ }^{112}$ J. Sperka, Elżbieta z Pilicy Granowska i król Władysław Jagiełło. Kulisy wielkiej miłości, [w:] Miłość w czasach dawnych, red. B. Możejko, A. Paner, Gdańsk 2009, s. 113.

${ }^{113}$ Jana Długosza Roczniki czyli Kroniki..., s. 74, 76; J. Tęgowski, Przodkowie Zofii..., s. 32.

${ }^{114}$ Koronacja Elżbiety spotkała się z dużym sprzeciwem przeciwników królewskiego małżeństwa, zob. J. Sperka, Elżbieta z Pilicy..., s. 114-116. 
Po śmierci Elżbiety Granowskiej (1420 r.) wysunięto projekt małżeństwa Jagiełły z wdową po królu czeskim Wacławie IV, Ofką. Zamysł ten nie doszedł do skutku. Jak pisze Jadwiga Krzyżaniakowa monarcha prawdopodobnie poznał Sonkę podczas pobytu w Drucku u księcia Semena $^{115}$. Wówczas zwrócił się do Witolda z prośbą o pośrednictwo w uzyskaniu ręki siostrzenicy jego żony. Nie ma informacji o tym, czy ślub Jagiełły z Holszańska, który odbył się 24 lutego 1422 r. w Nowogródku' ${ }^{116}$, poprzedziły rozmowy odnośnie do warunków zawarcia małżeństwa. Prawdopodobnie do takich układów doszło. Przyszła żona Jagiełły była wyznania prawosławnego i przed zawarciem związku małżeńskiego musiała przejść ponowny chrzest w obrządku katolickim, na którym otrzymała imię Zofia. Według przekazu Jana Długosza do ślubu doszło trzeciego dnia po chrzcie księżniczki. Jak podaje kronikarz „król Władysław pojmuje za żonę [...] księżniczkę Sońkę, spokrewnioną z nim w trzecim i czwartym stopniu"117. Zdaniem Bożeny Czwojdrak, para młoda powinna była wystąpić o dyspensę na zawarcie związku ${ }^{118}$, tymczasem w źródłach nie ma śladów o podjęciu takich działann ${ }^{119}$. Koronacja Zofii na królową Polski odbyła się 5 marca 1424 r. w katedrze krakowskiej i dokonał jej arcybiskup gnieźnieński Wojciech Jastrzębiec, w asyście arcybiskupa lwowskiego, trzech biskupów i w obecności legata papieskiego Branda da Castiglione ${ }^{120}$.

Starania Zygmunta I o rękę Barbary Zapolya zaczęły się w marcu 1511 r. ${ }^{121}$ Barbara była poddaną Władysława II Jagiellończyka, króla Czech i Węgier. Wobec silnych wpływów habsburskich na dworze węgierskim,

${ }^{115}$ E. Maleczyńska, Rola polityczna królowej..., s. 34-35; J. Krzyżaniakowa, J. Ochmański, Wtadystaw II Jagietto..., s. 271.

${ }^{116}$ Jana Długosza Roczniki czyli Kroniki..., s. 165; F. Sikora, Uroczystości koronacyjne królowej Zofii w 1424 r., [w:] Kościót, Kultura, Społeczeństwo. Studia z dziejów średniowiecza i czasów nowożytnych, Warszawa 2000, s. 163.

117 Tamże.

${ }^{118}$ B. Czwojdrak, Zofia Holszańska..., s. 19.

119 Z analizy wariantów pokrewieństwa Jagieły z Zofią przeprowadzonej przez J. Tęgowskiego wynika, że zachodziło prawdopodobnie pokrewieństwo między Jagiełłą a Zofia, jednakże „dopóki nie znajdą się nowe przesłanki źródłowe uzasadniające któryś z wariantów jako najbardziej pewny, dopóty sprawa musi pozostać w sferze prawdopodobnych hipotez", J. Tęgowski, Przodkowie Zofii..., s. 45.

${ }^{120}$ E. Maleczyńska, Rola polityczna królowej..., s. 49; J. Tegowski, Pierwsze pokolenia..., s. 128; F. Sikora, Uroczystości koronacyjne królowej..., s. 169 i n.

${ }^{121}$ Dr A. Hirschberg, O życiu i pismach..., s. 100; L. Finkel, Sprawy wschodu przed soborem laterańskim r. 1512, [w:] Ksiega pamiatkowa Uniwersytetu Lwowskiego ku uczczeniu 500 rocznicy fundacji Jagiellońskiego Uniwersytetu Krakowskiego, Lwów 1900, s. 18; K. Baczkowski, Kongres Wiedeński..., s. 79. 
wrogich Zapolyom, sprawę prowadzono w tajemnicy ${ }^{122}$. Zastosowano wybieg polegający na stworzeniu sytuacji, aby inicjatywa małżeństwa wyszła od Władysława, króla węgierskiego i czeskiego, do którego młodszy brat Zygmunt zwrócił się o pomoc w kwestii decyzji dotyczącej partnerki. Misję pozyskania Władysława zlecono Piotrowi Tomickiemu, archidiakonowi krakowskiemu, wysłanemu w poselstwie do króla Węgier i Czech. $\mathrm{Na}$ tajnej audiencji u Władysława (2 kwietnia t.r.) ${ }^{123}$, Tomicki wyjawił zamiar króla polskiego zawarcia związku małżeńskiego z Węgierką, z prośbą o wskazanie odpowiedniej kandydatki. Pozyskano równocześnie królewskiego lekarza i spowiednika Michała Hammela, zwolennika Zapolyów, którego zadaniem było nakłonienie monarchy Węgierskiego, aby ten zaproponował Barbarę Zapolyę, jako najgodniejszą kandydatkę na żonę Zygmunta, młodszego brata króla ${ }^{124}$. Po uzyskaniu zgody Władysława Węgierskiego ${ }^{125}$, do Krakowa z początkiem listopada przybyli posłowie celem uzgodnienia warunków układu małżeńskiego ${ }^{126}$. Kazimierz, książę cieszyński, był wyrazicielem interesów rodu Zapolyów, a Michał Hammel był posłem króla Władysława. Dowiadujemy się o tym z komentarza Stanisława Górskiego i z listu Zygmunta I do arcybiskupa gnieźnieńskiego Jana Łaskiego ${ }^{127}$. Układy, zapoczątkowane w kwietniu we Wrocławiu przez Piotra Tomickiego, zakończono podpisaniem w Krakowie 2 grudnia 1511 r. „zmówin małżeńskich”"128, czyli kontraktu małżeńskiego. Król wysłał poselstwo „do narzeczonej [...] Barbary w osobach biskupa poznańskiego Jana Lubrańskiego, kasztelana sandomierskiego Krzysztofa Szydłowieckiego oraz starostę poznańskiego i starostę generalnego Wielkopolski Łukasza Górkę"129. Zostali oni wyposażeni w pełnomocnictwo, aby w trakcie pobytu w Trenczynie, siedzibie Zapolyów, zawrzeć w imie-

\footnotetext{
${ }^{122}$ K. Liske, Kongres Wiedeński roku 1515..., s. 13.

${ }^{123}$ M. Rekettyés, Stosunki polityczne..., s. 100.

${ }^{124}$ K. Baczkowski, Kongres Wiedeński..., s. 79.

${ }^{125}$ I. Commentarius, [w:] AT, t. II, s. 1; Ks. B. Przybyszewski, Barbara Zapolya..., s. 22.

${ }^{126}$ K. Baczkowski, Kongres Wiedeński..., s. 79, 83. O zabiegach mających skłonić Władysława Węgierskiego do udzielenia zgody na ten związek małżeński, tamże, s. 76-79.

${ }^{127}$ I. Commentarius, [w:] AT, t. II, s. 1; III. Sigismundus, Rex, Consiliariis Regni..., s. 4.
} Król Zygmunt I informował Jana Łaskiego: „Zawarliśmy więc przy pośrednictwie posła Braterskiego Majestatu traktaty ze wspomnianym księciem Kazimierzem i wyraziliśmy zgodę tak radą Najjaśniejszego Króla Węgier, jak częstymi do tego skłonieni namowami", cyt. za Ks. B. Przybyszewski, Barbara Zapolya..., s. 23-24

${ }^{128}$ Wesele Zygmunta I z Barbara Zapolska, [w:] M. Wiszniewski, Pomniki historyi i literatury Polskiey, t. IV, Kraków 1837, s. 119; Jodok L. Decjusz, Księga o czasach..., s. 56; W. Abraham, Zawarcie małżeństwa w pierwotnem prawie polskiem, Lwów 1925, s. 125-138; Ks. B. Przybyszewski, Barbara Zapolya..., s. 23, 27; K. Baczkowski, Kongres Wiedeński..., s. $79,83$.

${ }^{129}$ Jodok L. Decjusz, Księga o czasach..., s. 61. 
niu monarchy małżeństwo per procura z Barbarą Zapolyą ${ }^{130}$. Barbara przybyła do Krakowa 7 lutego 1512 r. W niedzielę, następnego dnia, doszło do uroczystości zaślubin, a koronacji królowej dokonał arcybiskup gnieźnieński Jan Łaski.

Zygmunt August, jak przypuszcza Anna Dembińska, poznał Barbarę w 1543 r., gdy pojechał na Litwę celem przejęcia spadku po bezpotomnej śmierci Stanisława Gasztołda, wojewody trockiego ${ }^{131}$. Projekt małżeństwa z Barbara, zdaniem J. Jasnowskiego, powstał prawdopodobnie w pierwszej połowie $1547 \mathrm{r}$. Brak jest informacji, czy ślub został poprzedzony zawarciem kontraktu małżeńskiego. Ślub przypuszczalnie odbył się w czerwcu lub na początku lipca t.r. ${ }^{132}$ i był utrzymywany w ścisłej tajemnicy. Monarcha za radą Mikołaja Czarnego i pozyskanych w Koronie przyjaciół, zdecydował o zawiadomieniu rodziców o swym małżeństwie. Uczynił to pod koniec sejmu odbywającego się w Piotrkowie (15 grudnia 1547 - 5 lutego 1548 r. $)^{133}$. Litewskiej radzie wielkoksiążęcej, zebranej na naradę w zamku w Wilnie, przedstawił oficjalnie Barbarę jako małżonkę 17 kwietnia 1548 r. Prezentacja nastąpiła po nadejściu wiadomości o śmierci starego króla Zygmunta ${ }^{134}$. Od tego dnia Radziwiłłówna, jako małżonka królewska, zamieszkała na zamku wileńskim. Sprawa koronacji przeciaggnęła się aż do jesieni $1550 \mathrm{r}$. z uwagi na wrogie odnoszenie się królowej Bony i dużej części szlachty do

130 „Treścią niniejszego dokumentu podajemy do wiadomości [że dajemy] tymże posłom pełną władzę zawarcia w naszym imieniu z samą panną Barbarą narzeczeństwa i według traktatów przedtem z nami przez zastępcę najjaśniejszego Władysława króla Węgier itd. oraz przez najjaśniejszą panią matkę Jadwigę oraz Jana i Jerzego powyżej wspomnianych hrabiów - na mocy specjalnego ich upoważnienia z nami zawartych - tejże Pannę z nami zaręczyć oraz dalej działać, traktować aż do zawarcia małżeństwa [...], IV. Upoważnienie do zrękowin królowej (Barbary)”, cyt. za Ks. B. Przybyszewski, Barbara Zapolya..., s. 27; zob. XX. Mandatum ad desponsandam Reginam, [w:] AT, II s. 17; „Wysłał Król Panów Rady swojej na Węgry, którzy z mocy sobie danej, małżeństwo w Trenczynie zawarli i małżonkę do królestwa przywiedli" w: Wesele Zygmunta I z Barbara Zapolską..., s. 119; J. Kieszkowski, Kanclerz Krzysztof Szydtowiecki..., s. 180.

${ }^{131}$ A. Dembińska, Zygmunt I..., s. 287, przyp. 36; J. Jasnowski, Mikołaj Czarny Radziwitt..., s. 13 .

132 J. Jasnowski, Mikołaj Czarny Radziwiłt..., s. 16; A. Sucheni-Grabowska, Zygmunt August..., s. 126.

${ }^{133}$ M. Baliński, Pamiętniki o Królowej Barbarze..., s. 90-91, 100; J. Jasnowski, Mikołaj Czarny Radziwiłt..., s. 27-28; A. Sucheni-Grabowska, Zygmunt August..., s. 128-129.

134 „,...] wolą Bożą i dziwnem zrządzeniem Jego już z Barbarą Radziwiłłówną jako z domu przedniejszego w Litwie, z zacnego ojca urodzona, brał ślub obyczajem powszechnym chrześcijańskim. Przeto jej potem i przeciwnicy powinną cześć musieli wyrządzić, jako królowej swej", cyt. za A. Przeździecki, Jagiellonki polskie..., s. 195; M. Baliński, Pamiętniki o Królowej Barbarze..., s. 119-120; A. Sucheni-Grabowska, Zygmunt August..., s. 138. 
Barbary ${ }^{135}$. Koronacja odbyła się w katedrze wawelskiej 7 grudnia $1550 \mathrm{r}$. Powiązana była z hołdem pruskim ${ }^{136}$.

W czasie, który nastąpił po śmierci Cecylii Renaty Habsburżanki, pierwszej żony Władysława IV, Francja podjęła zabiegi zmierzające do osłabienia wpływów habsburskich w Polsce ${ }^{137}$. Służyć temu miały m.in. propozycje matrymonialne, z którymi miał wystąpić do króla wdowca poseł francuski. Pod uwagę brane były francuskie księżniczki ${ }^{138}$. Król Polski nosił się z zamiarem małżeństwa z królową szwedzką Krystyną. W trakcie drugiej audiencji francuskiego posła de Brégy, w październiku 1644 r., król zwrócił się do niego z prośbą o poparcie jego starań w Sztokholmie ${ }^{139}$. Poseł francuski wystąpił z sugestią „,niech weźmie towarzyszkę raczej z Francji, rezygnując z pokrewieństwa austriackiego i niemieckiego. Królowa regentka Francji przedstawiła królowi kilka propozycji do wyboru: jedynaczkę księcia orleańskiego, stryja królewskiego ${ }^{140}$, drugą Marię de Nevers, dziedziczkę kilku księstw, trzecią z rodu Gwizjuszów $^{141}$, czwartą Longueville ${ }^{142}$, piątą Kondeuszkę"143. Na tajnym posiedzeniu 20 marca 1645 r. „,senat zgodził się, by król mógł ponowić śluby małżeńskie" ${ }^{144}$. Na żądanie Władysława IV dostarczono portrety księżniczek francuskich. Wybór pozostawiono monarsze, tym niemniej dwór francuski, jako osobę najbardziej odpowiadającą Francji, zalecał Marię de Nevers ${ }^{145}$. Król opowiedział się właśnie za jej osobą ${ }^{146}$. Po uzgodnieniu

${ }^{135}$ J. Jasnowski, Mikołaj Czarny Radziwiłt..., s. 29 i n. Bona nie chciała się pogodzić z utratą władzy, S. Cynarski, Zygmunt August..., s. 52.

${ }^{136}$ W. Bogatyński, Z dziejów małżeństwa Zygmunta Augusta..., s. 207; J. Jasnowski, Mikołaj Czarny Radziwitt..., s. 54-55; A. Sucheni-Grabowska, Zygmunt August..., s. 264-266.

${ }^{137}$ M. Serwański, Francja wobec Polski..., s. 316-317.

${ }^{138}$ L. Kubala, Jerzy Ossoliński, t. I, Lwów 1883, s. 246; W. Czapliński, Władysław IV wobec wojny..., s. 94-96; M. Serwański, Francja wobec Polski..., s. 323-324, 335, 341.

${ }^{139}$ A. S. Radziwiłł, Pamiętnik o dziejach..., t. II, s. 419; M. Serwański, Francja wobec Polski..., s. 326-327.

${ }^{140}$ Anna Maria Ludwika, córka Gastona Orleańskiego, stryja Ludwika XIV, księżna de Montpensier, zwana la Grande Mademoiselle, ur. 1627 r.

${ }^{141}$ Maria de Lorraine, ur. 1615 r. córka Karola de Guise i Henrietty de Montpensier.

${ }^{142}$ Anna Genowefa, księżna de Longueville, siostra Ludwika Wielkiego Kondeusza, ur. 1619.

${ }^{143}$ Maria, córka Karola de Conde i Anny de Montofié; A. S. Radziwiłł, Pamiętnik o dziejach..., s. 418-419.

${ }^{144}$ A. S. Radziwiłł, Pamiętnik o dziejach..., s. 443; W. Czapliński, Władysław IV wobec wojny..., s. 105.

${ }^{145}$ W. Czapliński, Władysław IV wobec wojny..., s. 106; M. Serwański, Francja wobec Polski..., s. 335, 341

146 „Król [...] odezwał się do Rzplitey że się chce żenić, iż ma inklinacią do Maryey Ludowiki Karola Gonzagi Xiencia Mantuańskiego curki Xienżney Niwerneńskiey, w Królestwie Francuskim [...]" w: Pamiętniki do panowania Zygmunta III, Władystawa IV..., s. 263. 
17 lipca 1645 r, wstępnych warunków umowy małżeńskiej przez kanclerza wielkiego koronnego Jerzego Ossolińskiego z posłem francuskim Nicolasem Flecelles, hrabią de Bregy ${ }^{147}$, wyruszyło do Francji uroczyste poselstwo, na czele z wojewodą poznańskim Krzysztofem Opalińskim i Wacławem Leszczyńskim, biskupem warmińskim, po Ludwikę Marię ${ }^{148}$. „[D]la umowy i zamknienia kontraktów" został wcześniej wysłany Gerard Denhoff, wojewoda pomorski ${ }^{149}$. Uzgodniony kontrakt małżeński podpisano 26 września w Fontainebleau. Ceremonia ślubna i koronacyjna ${ }^{150}$ odbyła się 5 listopada 1645 r. w kaplicy Palais-Royal w Luwrze w obecności Ludwika XIV i jego dworu ${ }^{151}$. Ślubu per procura z królową Ludwiką Marią w zastępstwie króla Władysława IV dopełnił jego pełnomocnik Krzysztof Opaliński, wojewoda poznański ${ }^{152}$. Do Warszawy królowa przybyła 10 marca 1646 r. Tego samego dnia ślubu parze królewskiej udzielił w kościele pw. św. Jana nuncjusz papieski Jan de Torres, potwierdzając ślub, który odbył się w Paryżu ${ }^{153}$. Koronacji nowej królowej dokonał w katedrze wawelskiej 15 lipca 1646 r. prymas Maciej Łubieński arcybiskup gnieźnieński ${ }^{154}$.

${ }^{147}$ XX. Points consentis entre le sieur Brégy de Flécelles et le Sénateurs de Pologne pour le marriage de la P-sse; Warszawa 17 lipca (A.S.Z.F. Kopia), [w:] K. Waliszewski, Polsko-francuskie..., s. 201; listy ambasadora francuskiego de Bregy Flecelles z 13 i 19 lipca 1645 r. w: Portofolio Królowej Maryi Ludwiki czyli zbiór listów, aktów..., przekład z francuskiego na język polski K. Hr. Raczyńska, Hr. J. Radolińska, R. Ziołecki i Jastrzębski, wyd. Hr. E. Raczyński, t. I, Poznań 1844, s. 12, 15-16; W. Czapliński, Władysław IV wobec wojny..., s. 111 (273); M. Serwański, Francja wobec..., s. 342-344, 346-347 przyp. 31; zob. A. S. Radziwiłł, Pamiętnik..., t. II, s. 453.

${ }^{148}$ Wypis z podróży Pani de Guebriant, postowej nadzwyczajnej do Polski..., s. 122; Stanisława Oświęcima Dyaryusz 1643-1651, wyd. dr W. Czermak, Kraków 1907, s. 78.

${ }_{149}$ Tamże, list ambasadora francuskiego de Bregy Flecelles z 13 lipca 1645 r. w: Portofolio Królowej Maryi..., s. 9-10.

${ }^{150}$ Koronacja została przeprowadzona po zakończeniu mszy, mszę odprawiał i koronacji dokonał bp warmiński.

${ }^{151}$ Kardynał Retz, Pamiętniki, przekład Al. i M. Bocheńscy, t. I, Warszawa 1981, s. 71; F. de Motteville, Anna Austriaczka i jej dwór, wybór i przekład I. Wachlowska, wstęp i przypisy Z. Libiszowska, Warszawa 1978, s. 94-95.

${ }^{152}$ F. de Motteville, Anna Austriaczka i jej dwór..., s. 90, 94-95; Pamiętniki do panowania Zygmunta III, Władystawa IV..., s. 264; Le grand Conde et le duc D'Engihien. Lettres inédites à Marie-Louise de Gonzague, reine de Pologne, sur la cour de Louis XIV (1660-1667) publiées d'après le manuscrit original autographe de Chantilly par Emil Magne, ed. Emil-Paul Freres, Paris 1920, s. 11.

153 Stanisława Oświęcima Dyaryusz..., s. 123; A. S. Radziwiłł, Pamiętnik..., t. II, s. $482-483$.

${ }^{154}$ A. S. Radziwiłł, Pamiętnik..., t. II, s. s. 501-502. 


\section{Posag i oprawa królowych}

Kobieta wychodząc za mąż wnosiła do rodziny męża posag. Celem posagu było dopomożenie małżonkowi w ponoszeniu ciężarów małżeństwa i zapewnienie żonie utrzymania na wypadek śmierci męża. Nie stawał się on własnością męża. Mąż zabezpieczał wartość posagu na połowie swego majątku ${ }^{155}$. W umowie małżeńskiej określano m.in. wysokość posagu, wysokość wiana i dobra, na których zabezpieczony był posag, wyprawę panny młodej i prezent poślubny ${ }^{156}$.

Pogląd „o bogatym posagu, złożonym z dóbr ziemskich” należących do Elżbiety wyraziła Maria R. Nitkiewicz, analizując paszkwil Stanisława Ciołka wymierzony w związek Granowskiej z królem ${ }^{157}$. Literatura milczy w przedmiocie posagu Granowskiej, podobnie jest z jej wianem ${ }^{158}$.

Nie znamy umowy małżeńskiej określającej wysokość posagu czwartej żony Jagiełły. Odnośnie do jej posagu w literaturze występują dwa poglądy. O Sonce Holszańskiej Długosz pisze, że „nie miała wnieść ze sobą żadnego posagu"159. Z kolei o posagu dowiadujemy się pośrednio z dokumentów wystawionych po koronacji królowej w marcu 1424 r. Uwagę na to zwrócił Franciszek Sikora. W dyplomie z 9 marca monarcha przyłączył do dóbr nowomiejskich korczyńskich, należących do dóbr wiennych, dwie wsie z folwarkami. Dwa dni później dodał do zapisanego po ślubie wiana ziemie sanocką i inowrocławską oraz powiat nieszawski i oprawił żonie 10000 grzywien posagu i 10000 grzywien wiana zapisanych na ziemiach i powiatach: radomskim, sądeckim, bieckim, nowomiejskim korczyńskim i żarnowieckim ${ }^{160}$. Ustalenia F. Sikory stawiają informację zamieszczoną u Długosza pod znakiem zapytania. Z kolei Urszula Borkowska przypuszcza, że posag wynosił 20000 grzywien ${ }^{161}$. Jest to nieporozumienie. $Z$ odesłania do źródła wynika, że kwota 20000 grzywien to suma posagu i wiana zapisana

${ }^{155}$ P. Burzyński, Prawo polskie prywatne, t. II obejmujący [...] Cz. II, Prawo rodzinne, Cz. III, Prawo majątkowe, Kraków 1871, s. 136 i n.

${ }^{156}$ U. Borkowska OSU, „Pacta Matrimonialia”..., s. 51.

157 Autorka powołuje się na interpretacje historyków, bez wskazania źródła, zob. M. R. Nitkiewicz, Królowa Elżbieta z Pilczy i Łańcuta, trzecia żona Władysława Jagiełty, Łańcut 2003, s. 114.

${ }^{158}$ U. Borkowska OSU, „Pacta Matrimonialia”..., s. 55.

${ }^{159}$ Jana Długosza Roczniki czyli Kroniki..., s. 165, za nim E. Maleczyńska, Rola polityczna królowej Zofii Holszańskiej..., s. 23; J. Tęgowski, Przodkowie Zofii..., s. 28;

${ }^{160}$ F. Sikora, Uroczystości koronacyjne królowej Zofii..., s. 172-173; podobnie B. Czwojdrak, Zofia Holszańska..., s. 20, 25.

${ }^{161}$ U. Borkowska OSU, „Pacta Matrimonialia”..., s. 55. 
na określonych dobrach królewskich, stanowiąca oprawę $e^{162}$. Z oprawy tej, w przypadku śmierci męża, gdyby Zofia powtórnie wyszła za mąż, spadkobiercy monarchy powinni ją spłacicín ${ }^{163}$.

W kontrakcie małżeńskim Zygmunta I Jagiellończyka i Barbary Zapolyi uzgodniono, że panna młoda wniesie posag wysokości 100000 dukatów ${ }^{164}$. Wysokość posagu równała się posagom wnoszonym przez przedstawicielki dynastii Habsburgów do związków małżeńskich zawieranych przez nie. Tytułem posagu i wiana monarcha zapisał Barbarze kwotę 200000 dukatów na Nowym Mieście Korczynie, Wiślicy, Żarnowcu, Radomiu, Jedlni, Kozienicach, Stężycy, Radostowicach, Łęczycy, Przedeczu i Kłodawie. $Z$ uwagi na fakt, że niektóre $\mathrm{z}$ tych dóbr były uposażeniem tymczasowym królewny Elżbiety Jagiellonki, w ich miejsce Zygmunt zapisał Biecz i Sochaczew, w miejsce Łobzowa będącego w zastawie u Jana Bonera zapisał 200 zł węgierskich rocznego dochodu z żup wielickich ${ }^{165}$. Królowa zrzekła się, za zgodą Zygmunta I, wszelkich praw do sukcesji majątku Zapolyów na Węgrzech.

W źródłach brak informacji o posagu wniesionym przez Barbarę Gasztołdową Zygmuntowi Augustowi ${ }^{166}$. W trakcie obrad sejmowych, wobec ostrych sprzeciwów posłów izby poselskiej względem małżeństwa krola, monarcha zadeklarował, że o oprawie Barbary nie będzie nic „,czynić bez namowy z Radami koronnymi do sejmu drugiego"167. Król 1 maja 1549 r. ustanowił „oprawę wiana” Barbary zapisując jej „własność naszą ojczystą hospodarska, prawem i obyczajem oprawy wianowej" (następuje wyliczenie dóbr hospodarskich i praw z nimi związanych) ${ }^{168}$. W akcie

${ }^{162}$ Dok. nr 1128: Król Jagiełto zapisuje wiano żonie swej Zofii w: Codex Epistolaris Vitoldi Magni Ducis Lithuaniae 1376-1430, ed. A. Prochaska, Kraków 1882, s. 619-620.

${ }^{163}$ A. Winiarz, Polskie prawo majątkowe-matżeńskie w wiekach średnich, [w:] RAU WHF, Serya II, t. XII, Kraków 1899, s. 223 i n.; B. Lesiński, Stanowisko kobiety w polskim prawie ziemskim do połowy XV wieku, Wrocław 1956, s. 114 i n.; J. Pielas, Wdowa-matka a kwestie majatkowe w rodzinach szlachty koronnej w XVII wieku, [w:] Społeczeństwo Staropolskie, Seria nowa, t. III, red. A. Karpiński, Warszawa 2011, s. 189-190; T. Szulc, Status materialny Marii Kazimiery..., s. 185.

${ }^{164}$ A. Przeździecki, Jagiellonki Polskie..., t. I, s. 13; K. Baczkowski, Kongres wiedeński..., s. 83; M. Rekettyés, Stosunki polityczne..., s. 104.

${ }^{165}$ M. Dogiel, Codex diplomaticus Regni Poloniae et Magni Ducatus Lithuaniae, t. I, cz. 1-2, Vilno 1758, dok. XLV, s. 119-121; A. Przeździecki, Jagiellonki Polskie..., s. 13; U. Borkowska OSU, „Pacta Matrimonialia”..., s. 56, przyp. 81; S. A. Sroka, Jadwiga Zapolya..., s. 27-28.

166 Z. Wdowiszewski, Genealogia Jagiellonów..., s. 105; U. Borkowska OSU, „Pacta Matrimonialia"..., s. 56.

${ }^{167}$ Dyaryusz sejmu piotrkowskiego 1548..., s. 252.

${ }^{168}$ Pisma historyczne Michała Balińskiego, t. I, Warszawa 1843, nr X, s. 314-315. W literaturze, w kontekście powyższego aktu, autorzy posługują się terminem oprawa: E. Kotłubaj, Galerja Nieświeska portretów..., s. 56; Encyklopedia powszechna, t. II, Warszawa 1860, 
królewskim nie wspomina się o posagu, trudno więc traktować decyzję Zygmunta Augusta jako odwzajemnienie męża za majątek wniesiony przez żonę. Celem oprawy wiennej było, aby ,jej m. po żywocie naszem mieszkać i stan swój uczciwy, jako na jej m. małżonkę naszą przynależy, w dobrym dostatku wieść i zachować mogła"169. Na wypadek wcześniejszej śmierci króla dochody z hospodarskich dóbr oprawnych miały zapewnić środki na utrzymanie królowej wdowy.

W kontrakcie małżeńskim Władysława IV z Ludwiką Marią de Gonzaga ustalono wysokość posagu na kwotę 700000 talarów ${ }^{170}$. Była to ogromna kwota, niespotykana w postanowieniach umów małżeńskich zawieranych przez poprzedników Władysława IV. Jean de Laboureur pisał, że Ludwik XIV i regentka Anna Austriaczka „Przyrzekli mu [królowi polskiemu] ją [Ludwikę Marię] z posagiem siedmiokroć sto tysięcy talarów, za które zaręczyli, albo raczej za dług własny przyjęli, bo interesa domu Newerskiego nie dozwalały mu wtedy tak znacznej wypłacić sumy"171. Z kwoty 700000 talarów monarcha Polski mógł dowolnie rozporządzać kwotą 200000 talarów, będącą darem Ludwika XIV. Suma ta miała być wpłacona $\mathrm{w}$ dwóch transzach. Pierwsza $\mathrm{w}$ przeddzień zawarcia związku małżeńskiego, kolejne 100000 talarów natomiast na koniec roku $1646^{172}$. Pozostała część była do wyłącznej dyspozycji Ludwiki Marii. W kontrakcie zawarto postanowienia traktujące o oprawie królowej i prezencie ślubnym. Władysław IV zobowiązany był do uregulowania na najbliższym sejmie oprawy królowej wedle zwyczaju w postaci dóbr, „posiadłości w miastach, wsiach, twierdzach, ziemiach Królestwa Polskiego i Wielkiego Księstwa Litewskiego z nieruchomościami właściwymi dla godności Królowej” ${ }^{173}$. Ustanowienie „daru ślubnego godnego Królowej" pozostawiono do decyzji króla polskiego ${ }^{174}$.

s. 868, s.v. Barbara Radziwitłówna (autor J. Bartoszewicz); A. Przeździecki, Jagiellonki Polskie..., s. 212 przyp. 1; Z. Kuchowicz, Barbara Radziwiłłówna..., s. 196; E. Rudzki, Polskie królowe..., t. I, s. 259; M. Ferenc, Mikołaj Radziwiłł „Rudy”..., s. 124. Niewłaściwego określenia oprawa posagowa użył Z. Wdowiszewski, Genealogia Jagiellonów..., s. 105.

${ }^{169}$ Pisma historyczne Michała Balińskiego..., s. 314.

${ }^{170}$ Szerzej o posagu i oprawie Ludwiki Marii w: T. Szulc, Status prawnomajatkowy Ludwiki Marii...

171 „Wypis z podróży Pani de Guebriant posłowej nadzwyczajnej do Polski..., s. 122; B. Rudomicz, Efemeros czyli Diariusz prywatny pisany w Zamościu w latach 1656-1672. Część pierwsza 1656-1664, przeł. z jęz. łac. W. Froch, oprac. historyczne i historycznoprawne M. L. Klimentowski, Lublin 2002, s. 257.

${ }^{172}$ M. Dogiel, Codex diplomaticus Regni..., Dok. IX Pacta matrimonialia [...], s. 470, pkt IV.

${ }^{173}$ Tamże, s. 471, pkt X.

${ }^{174}$ Tamże, s. 472, pkt XI. 


\section{Wnioski}

Trzy z pięciu wybranek królów polskich były ich poddanymi, dwie poddanymi obcych monarchów, którzy na zawarcie przez nie związku małżeńskiego z obcym władcą wyrazili zgodę. Wola o wyborze kandydatki należała do monarchy, tym niemniej niejednokrotnie korzystał $\mathrm{z}$ rady swoich bliskich. Decyzja o wyborze spotykała się z różnych powodów z krytyką rodziny i poddanych. Zasadniczo monarchowie nie liczyli się z głosami sprzeciwów. Wyjątek stanowił Władysław IV, na żądanie którego, aby uciszyć krytykę, zadbano o zrównanie statusu społecznego jego wybranki ze statusem rodziny królewskiej. Zasadniczym motywem było dążenie do zapewnienia monarchii następcy tronu. W dwóch związkach z pięciu ten cel został osiągnięty. Pobudką do zawarcia małżeństwa Władysława IV z Ludwiką Maria, obok zapewne urody, było jej bogactwo i perspektywa uzyskania przezeń dużego posagu. Pomimo ograniczeń nakładanych na osoby koronowane $\mathrm{w}$ zakresie wyboru małżonki to do monarchy należała w tym zakresie ostateczna decyzja.

\section{Bibliografia}

Acta Tomiciana, t. II, Poznań 1852.

Baczkowski K., Kongres Wiedeński 1515 roku, Oświęcim 2015.

Baczkowski K., Państwo polsko-litewskie w koncepcjach Maksymiliana I, [w:] tenże, Polska i jej sąsiedzi za Jagiellonów, Kraków 2012.

Baliński M., Pamiętniki o królowej Barbarze żonie Zygmunta Augusta, t. I, Warszawa 1837.

Baliński M. Pisma historyczne, t. I, Warszawa 1843.

Besala J., Małżeństwa królewskie Jagiellonowie, Warszawa 2006.

Besala J. Zygmunt Stary i Bona Sforza, Poznań 2012.

Bielski M., Kronika Polska..., ks. V, Warszawa 1830, [w:] Zbiór Pisarzów Polskich, Część piąta, t. XVI, Warszawa 1830.

Bogatyński W., Z dziejów matżeństwa Zygmunta Augusta z Barbara, RAU WH-F Serya II, t. XXXIV, Kraków 1916.

Borkowska U. OSU, „Pacta Matrymonialia” Domu Jagiellonów, „Roczniki Humanistyczne" 2000, Zeszyt Specjalny Historia, t. XLVIII, z. 2 - Cursus mille annorum ofiarowane Profesorowi Eugeniuszowi Wiśniowskiemu, s. 44-60.

Borkowska u., OSU, Dynastia Jagiellonów w Polsce, Warszawa 2011.

Burzyński P., Prawo polskie prywatne [...], t. II, obejmujący [...] Cz. II, Prawo rodzinne, Cz. III, Prawo majątkowe, Kraków 1871.

Codex Epistolaris Vitoldi Magni Ducis Lithuaniae 1376-1430, ed. A. Prochaska, Kraków 1882.

Cravieri B., Kochanki i królowe. Władza kobiet, Warszawa 2008. 
Cynarski S., Zygmunt August, Wrocław-Warszawa-Kraków 2004.

Czapliński W., Władysław IV wobec wojny 30-letniej (1637-1645), Kraków 1937.

CzwojdrakB., Zofia Holszańska. Studiumodworzei rolikrólowejw późnośredniowiecznej Polsce, Warszawa 2012.

Decjusz Jodok L., Księga o czasach Zygmunta, Warszawa 1960.

Dembińska A., Zygmunt I. Zarys dziejów wewnętrzno-politycznych w latach 1540 1548, Poznań 1948.

Długosza Jana Roczniki czyli Kroniki Sławnego Królestwa Polskiego, księga jedenasta 1413-1430, red. i komentarz S. Gawęda, Warszawa 1985.

Dogiel M., Codex diplomaticus Regni et Magni Ducatus Lithuaniae, t. I, cz. 1-2, Vilno 1758.

Dubiecki M., Przedstawicielki dawnych dynastyj. Zarys historyczny, [w:] tenże, Obrazy i studya historyczne, Serya II, Warszawa 1899.

Duczmal M., Jagiellonowie. Leksykon biograficzny, Kraków 1996.

Dyaryusze sejmów koronnych 1548, 1553 i 1570 z rkp. wyd. J. Szujski, Kraków 1872 [SRP, I].

Encyklopedyja powszechna, t. II-XXVIII, Warszawa 1860-1868.

Felczak W, Historia Wegier, Wrocław-Warszawa-Kraków 1966.

Ferenc M., Mikołaj Radziwiłt "Rudy" (ok. 1515-1584). Działalność polityczna i wojskowa, Kraków 2008.

Finkel L., Sprawy wschodu przed soborem laterańskim r. 1512, [w:] Księga pamiątkowa Uniwersytetu Lwowskiego ku uczczeniu 500 rocznicy fundacji Jagiellońskiego Uniwersytetu Krakowskiego, Lwów 1900.

Gliczner E., Ksią̇ki o wychowaniu dzieci, przedmowa dr Wł. Wisłocki, Kraków 1876.

Górnicki Ł., Dzieje w Koronie Polskiej, oprac. H. Barycz, Wrocław 2003.

Grodziski S., Habsburgowie. Dzieje dynastii, Kraków 2013.

Héritier J., Katarzyna Medycejska, Warszawa 1981.

Hirschberg A., O życiu i pismach Justa Ludwika Decjusza 1485-1545, Lwów 1874 [odbitka z "Przewodnika Naukowego i Literackiego"].

Historia dyplomacji polskiej, t. I, Połowa X w. - 1572, red. M. Biskup, Warszawa 1982.

Hubert E., Midro A. T., W mroku genów europejskich rodów panujących, "Ananke” [biuletyn Galerii im Śleńdzinskich, Białystok] 2006, nr 1 (45).

Jasnowski J., Mikołaj Czarny Radziwiłt (1515-1565). Kanclerz i marszałek ziemski Wielkiego Księstwa Litewskiego, wojewoda wileński, Oświęcim 2014 (I wyd. 1939).

Kantecki K. P., Elżbieta trzecia żona Jagietty. Opowiadanie historyczne. Nadbitka z „Przeglądu Naukowego i Literackiego”, Lwów 1874.

Kardynał R., Pamiętniki, przekład Al. i M. Bocheńscy, t. I, Warszawa 1981.

Kieszkowski J., Kanclerz Krzysztof Szydłowiecki. Z dziejów kultury i sztuki zygmuntowskich czasów, Poznań 1912.

Kolankowski L., Zygmunt August, wielki książę Litwy, do roku 1548, Lwów 1913.

Konopczyński W., Dzieje Polski Nowożytnej, t. I, Warszawa 1986.

Kotłubaj E., Galerja Nieświeska portretów Radziwiłłowskich opisana przez [...], z drzeworytami M. Starkiewicza, czcionkami A. Marcinowskiego, Wilno 1857. 
Krzyżaniakowa J., Ochmański J., Władysław II Jagiełto, Wrocław-WarszawaKraków-Gdańsk-Łódź 1990.

Kubala L., Jerzy Ossoliński, t. I, Lwów 1883.

Kuchowicz Z., Barbara Radziwitłówna, Łódź 1976.

Kuczyński S. M., Król Jagiełło ok. 1350-1434, Warszawa 1985.

Le grand Conde et le duc D Engihien. Lettres inédites à Marie-Louise de Gonzague, reine de Pologne, sur la cour de Louis XIV (1660-1667) publiées d'après le manuscrit original autographe de Chantilly par Emil Magne, ed. Emil-Paul Freres, Paris 1920.

Lengnich G., Prawo pospolite Królestwa Polskiego..., t. I, Kraków 1761.

Lesiński B., Stanowisko kobiety w polskim prawie ziemskim do połowy XV wieku, Wrocław 1956.

Liske K., Kongres Wiedeński roku 1515, [w:] tenże, Studia z dziejów wieku XVI, Poznań 1867.

Magdziarz S., Anna Austriaczka, Warszawa 2013.

Maleczyńska E., Rola polityczna królowej Zofii Holszańskiej na tle walki stronnictw w Polsce w latach 1422-1434, Lwów 1936.

Motteville F. de, Anna Austriaczka i jej dwór, wybór i przekład I. Wachlowska, wstęp i przypisy Z. Libiszowska, Warszawa 1978.

Narbutt T., Pomniki do Dziejów Litewskich pod względem historycznym, dyplomatycznym, geograficznym itp. ... zebrane przez [...], Wilno 1846.

Niemcewicz J. U., Zbiór pamiętników historycznych o dawnej Polsce..., t. IV, Lipsk 1839.

Nitkiewicz M. R., Królowa Elżbieta z Pilczy i Łańcuta, trzecia żona Władysława Jagiełty, Łańcut 2003.

Orzechowskiego Stanisława polskie dialogi polityczne (Rozmowa około egzekucyjej i Quincunx), 1563-1564, wyd. J. Łoś, z objaśnieniami historycznymi S. Kot, Kraków 1919.

Oświęcim S., Dyaryusz 1643-1651, wyd. W. Czermak, Kraków 1907.

Pamiętniki do panowania Zygmunta III, Władysława IV i Jana Kazimierza z rkps. wydał K. Wł. Wójcicki, Warszawa 1846.

Pielas J., Wdowa-matka a kwestie majatkowe w rodzinach szlachty koronnejw XVII wieku, [w:] Społeczeństwo Staropolskie. Seria nowa, t. III, red. A. Karpiński, Warszawa 2011, s. 171-194.

Polski słownik biograficzny, t. I, Kraków 1935.

Polski słownik biograficzny, t. VI, Kraków 1948.

Portofolio Królowej Maryi Ludwiki czyli zbiór listów, aktów..., przekład z francuskiego na język polski K. Hr. Raczyńska, Hr. J. Radolińska, R. Ziołecki i Jastrzębski, wyd. Hr. E. Raczyński, t. I, Poznań 1844.

Prochaska A., Długosz o Elżbiecie trzeciej żonie Jagiełty, Lwów 1876.

Przeździecki A., Jagiellonki polskie w XVI wieku. Obraz rodziny i dworu Zygmunta I i Zygmunta Augusta Królów Polskich, t. I, Kraków 1868.

Przybyłowicz O. M., Elżbieta Granowska: trzecia żona Władysława Jagiełty. Życie codzienne królowej, „Kwartalnik Historii Kultury Materialnej” 1997, R. XLV, nr 1, s. 3-15. 
Przybyszewski B. Ks., Barbara Zapolya. Królowa Polski 1512-1515, Łańcut 2000.

Radziwiłł A. S., Pamiętniki, wyd. E. Raczyński, Poznań 1839.

Radziwiłł A. S., Pamiętniki o dziejach w Polsce, t. II, 1637-1646, przekład i opracowanie A. Przyboś, R. Żelewski, Warszawa 1980.

Rej Mikołaj z Nagłowic, Żywot człowieka poczcizwego, wyd. K. J. Turowski, Kraków 1859.

Rekettyés M., Stosunki polityczne i kulturalne polsko-wegierskie za Władystawa Jagiellończyka, Wrocław 1999.

Rozbiór krytyczny Annalium Poloniae Jana Dtugosz z lat 1385-1444, t. I, oprac.

St. Gawęda, K. Sieradzka, J. Radziszewska, K. Stachowska pod kierunkiem J. Dąbrowskiego, Wrocław-Warszawa-Kraków 1961.

Rudomicz B., Efemeros czyli Diariusz prywatny pisany w Zamościu w latach 16561672. Część pierwsza 1656-1664, przeł. z jęz. łac. W. Froch, oprac. historyczne i historycznoprawne M. L. Klimentowski, Lublin 2002

Rudzki E., Polskie Królowe. Żony Piastów i Jagiellonów, t. I, Warszawa 1985.

Serwański M., Francja wobec Polski w dobie wojny trzydziestoletniej (1618-1648), Poznań 1986.

Sikora F., Uroczystości koronacyjne królowej Zofii w 1424 r., [w:] Kościót, Kultura, Społeczeństwo. Studia z dziejów średniowiecza i czasów nowożytnych, Warszawa 2000, s. 161-179.

Sperka J., Elżbieta z Pilicy Granowska i król Władysław Jagiełło. Kulisy wielkiej miłości, [w:] Miłość w czasach dawnych, red. B. Możejko, A. Paner, Gdańsk 2009, s. 107-119. Sroka S. A., Piastówny na Wegrzech w dobie Jagiellonów, [w:] Ecclesia Kultura Potestas. Studia z dziejów kultury i społeczeństw, red. P. Krasa, A. Januszek, A. Zalewajek, W. Polak. Księga ofiarowana profesor Urszuli Borkowskiej OSU, Kraków 2006.

Stryjkowski M., Kronika Polska, Litewska, Żmudzka i wszystkiej Rusi [...], poprzedzone wiadomością o życiu i pismach Stryjkowskiego przez Mikołaja Malinowskiego..., Warszawa 1846.

Strzelecka A., Kobieta w polityce dynastycznej $i$ w życiu dworskim za panowania Władysława Jagiełty (Drogi badań), Pamiętnik VI Powszechnego Zjazdu Historyków Polskich w Wilnie 17-20 września 1935 r., I Referaty, przygotował do druku F. Podhorecki, Lwów 1935, s. 112-125.

Sucheni-Grabowska A., Zygmunt August Król Polski i Wielki Ksią̇ę Litewski 1520_ 1563, Warszawa 1996.

Szajnocha K., O królach i bohaterach polskich. Opowiadania, Kraków 1892.

Szulc T., Historiograficzny bilans polityki ostatniego z Jagiellonów, "Studia z Dziejów Państwa i Prawa Polskiego" 1995, t. II, s. 109-129.

Szulc T., Kochanki i nieprawe dzieci królów polskich w okresie elekcyjnym (w świetle ówczesnych relacji), „Studia z Dziejów Państwa i Prawa Polskiego” 2007, t. X, s. $127-145$.

Szulc T., Status materialny Marii Kazimiery Sobieskiej po jej koronacji, „Studia Prawno Ekonomiczne" 2014, t. XCI/1, s. 179-201.

Szulc T., Status prawnomajątkowy Ludwiki Marii de Gonzaga w świetle intercyz małżńskich z roku 1645 i 1649, "Studia Prawno Ekonomiczne” 2015, t. XCVI, s. 145-162. 
Toć jest dziwne a nowe. Antologia literatury polskiej średniowiecza, oprac. A. Jelicz, Warszawa 1987.

Tęgowski J., Pierwsze pokolenie Giedyminowiczów, Poznań-Wrocław 1999.

Tęgowski J., Przodkowie Zofii Holszańskiej czwartej żony Władysława Jagiełty, [w:] Genealogia. Studia i Materiaty Historyczne, t. VIII, red. M. Górny, PoznańWrocław 1996, s. 27-45.

Waliszewski K., Polsko-francuskie stosunki w XVII wieku. 1644-1667. Opowiadania i źródła historyczne ze zbiorów archiwalnych francuskich publicznych i prywatnych, Kraków 1889.

Wapowski B., Dzieje Korony Polskiej i Wielkiego Księstwa Litewskiego od roku 1380 do 1535 przez [...], wyd. M. Malinowski, t. I, Wilno 1847.

Wdowiszewski Z., Genealogia Jagiellonów, Warszawa 1968.

Wdowiszewski Z., Genealogia Jagiellonów i Domu Wazów w Polsce, Kraków 2005.

Winiarz A., Polskie prawo majątkowe-matżeńskie w wiekach średnich, [w:] RAU WH-F, Serya II, t. XII, Kraków 1899.

Wiszniewski M., Pomniki historyi i literatury Polskiey, wyd. [...], t. IV, Kraków 1837. Wójcik Z., Jan Sobieski 1629-1696, Warszawa 1983.

Wyrozumski J., Kazimierz Wielki, Wrocław-Warszawa-Kraków-Gdańsk-Łódź 1982.

Ziembicki W., Barbara Radziwiłłówna w oświetleniu lekarskim, Pamiętnik Szóstego Powszechnego Zjazdu Historyków Polskich w Wilnie 17-20 września 1935 r., t. I, Referaty, do druku przygotował F. Podhorecki, Lwów 1935, s. 144-162. 